\title{
Aquifer Characterization at the Veterans Administration Hospital, Tuscaloosa, Alabama
}

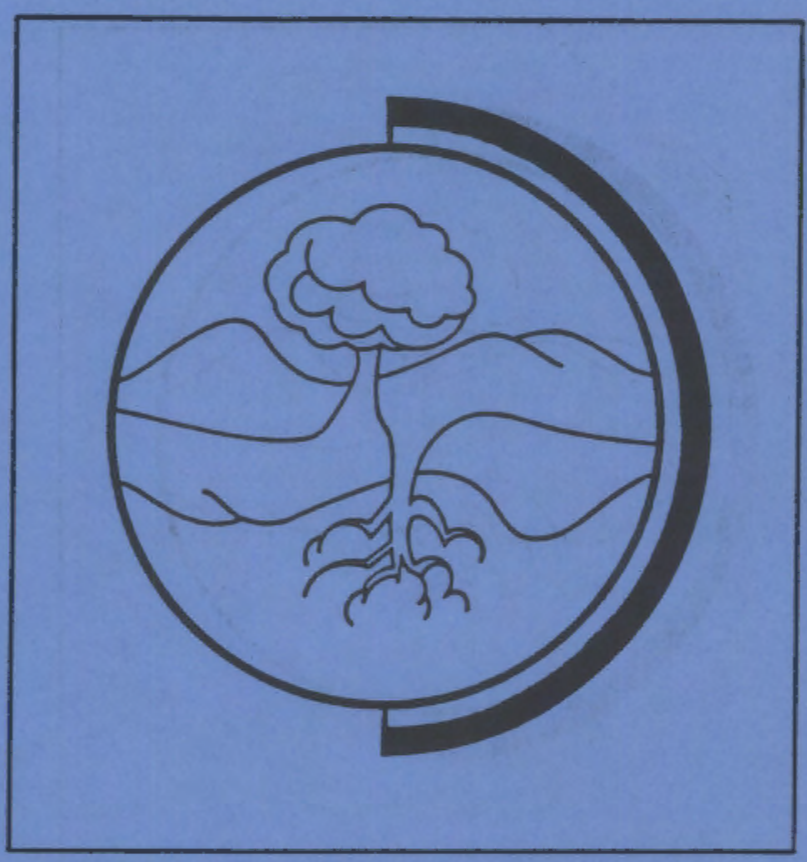

October 1989

Prepared for the U.S. Department of Energy under Contract DE-AC06-76RLO 1830

Pacific Northwest Laboratory

Operated for the U. S. Department of Energy

by Battelle Memorial Institute 


\title{
DISCLAIMER
}

This program was prepared as an account of work sponsored by an agency of the United States Government. Neither the United States Government nor any agency thereof, nor Battelle Memorial Institute, nor any or their employees, makes any warranty, expressed or implied, or assumes any legal liability or responsibility for the accuracy, completeness, or usefulness of any information, apparatus, product, or process disclosed, or represents that its use would not infringe privately owned rights. Reference herein to any specific commercial product, process, or service by trade name, trademark, manufacturer, or otherwise, does not necessarily constitute or imply its endorsement, recommendation, or favoring by the United States Government of any agency thereof, or Battelle Memorial Institute. The views and opinions of authors expressed herein do not necessarily state or reflect those of the United States Government or any agency thereof.

\author{
PACIFIC NORTHWEST LABORATORY \\ operated by \\ BATTELLE MEMORIAL INSTITUTE \\ for the \\ UNITED STATES DEPARTMENT OF ENERGY \\ under Contract DE-AC06-76RLO 1830
}

Printed in the United States of America

Available to DOE and DOE contractors from the

Office of Scientific and Technical Information, P.O. Box 62, Oak Ridge, TN 37831;

prices available from (615) 576-8401. FTS 626-8401.

Available to the public from the National Technical Information Service,

U.S. Department of Commerce, 5285 Port Royal Rd., Springfield, VA 22161.

NTIS Price Codes, Microfiche A01

\begin{tabular}{|c|c|}
\hline \multicolumn{2}{|c|}{ Printed Copy } \\
\hline Pages & $\begin{array}{c}\text { Price } \\
\text { Codes } \\
\end{array}$ \\
\hline$\overline{001-025}$ & $\overline{\mathrm{A} 02}$ \\
\hline $026-050$ & $\mathrm{~A} 03$ \\
\hline $051-075$ & $\mathrm{~A} 04$ \\
\hline $076-100$ & A05 \\
\hline $101-125$ & $\mathrm{~A} 06$ \\
\hline $126-150$ & $\mathrm{~A} 07$ \\
\hline $151-175$ & $\mathrm{~A} 0 \mathrm{~B}$ \\
\hline $176-200$ & $\mathrm{~A} 09$ \\
\hline $201-225$ & A10 \\
\hline $226-250$ & A11 \\
\hline $251-275$ & $\mathrm{~A} 12$ \\
\hline $276-300$ & A13 \\
\hline
\end{tabular}


W. E. Cronin

S. P. Luttrell

S. H. Hall

October 1989

Prepared for the U.S. Department of Energy under Contract DE-AC06-76RLO 1830

Pacific Northwest Laboratory

Richland, Washington 99352 
. 


\section{FOREWORD}

Seasonal thermal energy storage (STES) involves storing thermal energy, such as winter chill, summer heat, and industrial waste heat, for future use in heating and/or cooling buildings or for industrial processes. Widespread development and implementation of STES would significantly reduce the need to generate primary energy in the U.S. Recent data indicate that STES is technically suitable for providing $5 \%$ to $10 \%$ of the nation's energy, with major contributions in the commercial and industrial sectors and in district heating and cooling applications.

Aquifer thermal energy storage (ATES) is predicted to be the most costeffective technology for seasonal storage of low-grade thermal energy. Approximately $60 \%$ of the U.S. is underlain by aquifers that are potentially suitable for underground energy storage. Chill ATES has the potential to substantially reduce energy consumption and, especially, summer peak cooling electrical demand. However, the geohydrologic environment that the system will use is a major element in system design and operation, and this environment must be characterized for development of efficient energy recovery.

This report describes aquifer characterization of a site proposed for an ATES chill system at the U.S. Veterans Administration Hospital facility in Tuscaloosa, Alabama. The aquifer characterization work was conducted by the U.S. Department of Energy's Pacific Northwest Laboratory (Seasonal Thermal Energy Storage Program) in cooperation with the University of Alabama to assess utilization of chill ATES for cooling large institutional buildings for the Veterans Administration. The Pacific Northwest Laboratory is operated by Battelle Memorial Institute for the Department of Energy under contract DEAC06-76RL0 1830. The project was managed by Dr. C. Everett Brett, Director of the University of Alabama Natural Resources Center.

Land is D. Kannberg, Manager

Seasonal Thermal Energy Storage Program 
. 


\section{SUMMARY}

The Veterans Administration (VA) is studying the feasibility of aquifer thermal energy storage (ATES) at their Tuscaloosa, Alabama, facility. To determine the characteristics of the aquifer underlying the facility, the Pacific Northwest Laboratory gathered information about the environment of the aquifer and conducted tests to estimate the aquifer's transmissivity, ground-water flow direction, and velocity.

Seven wells were drilled at the VA site. It was found that ground-water flow direction at the site is generally toward the southwest. The magnitude of the gradient is approximately $2.5 \times 10^{-3}$ to $3 \times 10^{-3} \mathrm{ft} / \mathrm{ft}$. For six of the seven wells, clay lenses or thick clay layers appear to be acting locally as confining or semi-confining layers.

Three types of tests were conducted at the site: a step drawdown test, a constant discharge and recovery test, and a single-well tracer test. The data yielded responses suggesting leaky confined or delayed yield models for the aquifer. Drawdown and recovery versus time were matched to type curves for delayed yield to obtain estimates of transmissivity and storage. This recovery method gave the best fit to the drawdown-versus-time curves. Using this method it was found that transmissivity ranged from 500 to $9000 \mathrm{ft}^{2} / \mathrm{day}$ and storage ranged from $1.5 \times 10^{-4}$ to $4.5 \times 10^{-2}$ for the wells tested. Using the results of the pump and tracer tests simultaneous $1 y$, ground-water velocity was estimated to be approximately $0.8 \mathrm{ft} /$ day, with an effective porosity of approximately $12 \%$. 



\section{CONTENTS}

FOREWORD . . . . . . . . . . . . . . . . . . . . . i i

SUMMARY . . . . . . . . . . . . . . . . . . . . . . V

INTRODUCTION . . . . . . . . . . . . . . . . . . . . . . . . . 1

METHODS AND HYDROGEOLOGICAL SETTING . . . . . . . . . . . . . 3

METHODS OF STUDY. . . . . . . . . . . . . . . . 3

HYDROGEOLOGIC SETTING ................... . . 5

Stratigraphy ..................... 5

Aquifer Hydrogeology ................ 5

Hydraulic Gradient and Flow Direction. . . . . . . . . 7

TESTS AND RESULTS . . . . . . . . . . . . . . . . . . . 9

STEP DRAWDOWN TEST . . . . . . . . . . . . . . . . . 9

Method of Analysis.................. 9

Data Discussion. . . . . . . . . . . . . . 9

CONSTANT DISCHARGE AND RECOVERY TESTS . . . . . . . . . 10

Methods of Analysis................. 10

Data Discussion and Analysis . . . . . . . . . . 10

Summary of Test Analyses . . . . . . . . . . . . 12

SINGLE-WELL TRACER TEST . . . . . . . . . . . . . . . 13

Tracer Injection .................. 14

Field Measurements .................. 15

GROUND-WATER VELOCITY . . . . . . . . . . . . . . . 15

Darcy's Law. . . . . . . . . . . . . . . . 16

Tracer Test. ................. 17

Simultaneous Analysis.............. 18 


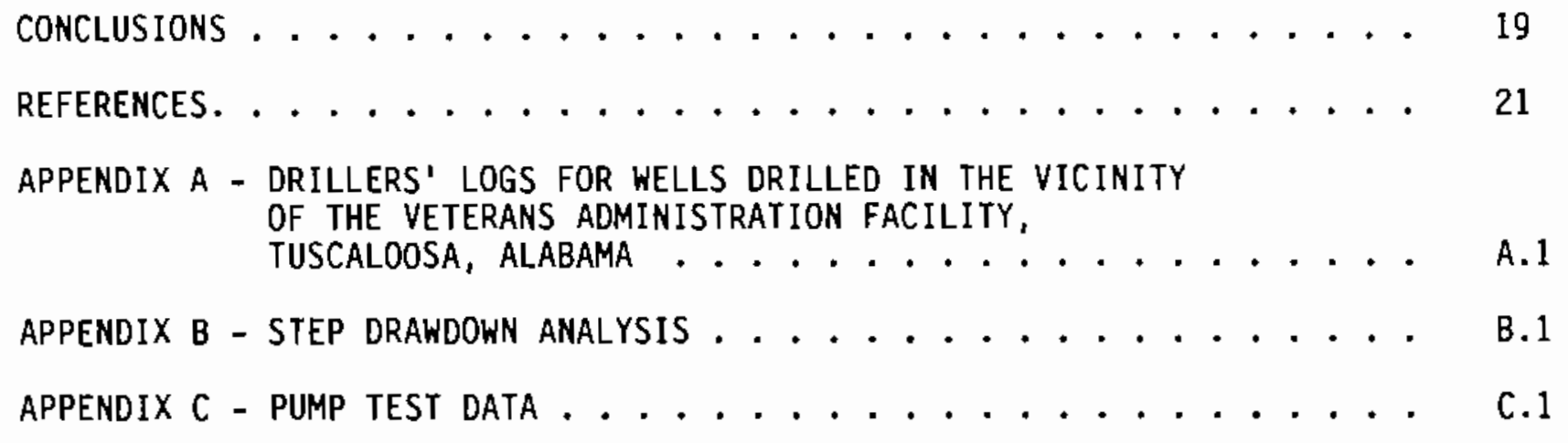




\section{FIGURES}

1 Locations of Wells at the VA Site.............. 4

2 Stratigraphic Diagram of Wells at the VA Site . . . . . . 6

3 Water Table Elevation Map of the VA Site, Measured May 24, 1989 . . . . . . . . . . . . . . . . 8

4 Concentration of Lithium Bromide Tracer Versus Time for the Pumpback Portion of the Tracer Test at the

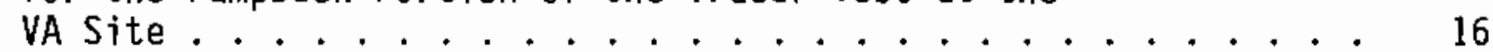

$5 \quad$ Plot of Velocity Versus Effective Porosity By Both the Tracer Test Method and Darcy's Law . . . . . . . . . . 17

\section{TABLES}

1 Well Design Information for VA Site.............. 3

2 Casing Elevations, Depth-to-Water Measurements, and Water-Level Elevations for Wells at the VA Site . . . . . . . . 7

3 Test Analyses Grouped by Method . . . . . . . . . . . . . . 13 
. 


\section{INTRODUCTION}

The Veterans Administration (VA) is studying the feasibility of aquifer thermal energy storage (ATES) for cooling purposes at their Tuscaloosa, Alabama, location. An understanding of aquifer characteristics and geometry, ground-water flow direction, and ground-water velocity are essential to determine the location and design of production and injection wells. The purpose of this study is to provide estimates of aquifer parameters, in order for feasibility studies to be conducted.

No previous hydrogeologic work has been conducted at the VA site. Previous work done by the Pacific Northwest Laboratory (PNL) staff(a) at the General Motors Harrison Division plant in Tuscaloosa and preliminary drilling directed by the University of Alabama were used as guides in planning aquifer tests at the VA site. (b)

Seven wells were drilled at the VA site, ranging from depths of 175 to $248 \mathrm{ft}$. The hydrogeologic setting of the site was determined, including the stratigraphy of the aquifer environment and the hydraulic gradient and flow direction. Then, three types of tests were performed: a step drawdown test, a continuous discharge and recovery test, and a single-well tracer test. The step drawdown test gave an estimate of the degree of efficiency of the pump wel1. The constant discharge and recovery test yielded estimates of transmissivity and storage properties. The single-well tracer test, using a lithium bromide ( $\mathrm{LiBr}$ ) solution, allowed an estimate of ground-water velocity. Results from these tests were used conjunctively in the calculation of ground-water velocity and effective porosity.

This report consists of chapters that describe the experimental method used and the hydrogeological setting of the VA site, describe the field tests and the experimental and calculated results, and finally summarize the findings. Appendixes contain the raw data of the field tests.

(a) Pacific Northwest Laboratory is operated by Battelle Memorial Institute for the U.S. Department of Energy under Contract DE-AC06-76RLO 1830.

(b) Letter report by S. P. Luttrell et al., Aquifer Characterization at the General Motors Harrison Division Plant, Tuscaloosa, Alabama, May 1989. 



\section{METHODS AND HYDROGEOLOGICAL SETTING}

\section{METHODS DF STUDY}

Al1 wells at the VA site were drilled for aquifer testing during May and June, 1989. Table 1 summarizes the construction of the wells and Figure 1 shows the locations of wells at the VA site.

Three types of tests were planned for the VA site: 1) a step drawdown test, 2) constant discharge and recovery test, and 3) single-well tracer injection/withdrawal test. Water levels in all wells were also measured for gradient analysis.

A step drawdown test was planned to determine the amount of drawdown that would be expected and the well entrance losses in the pumped well.

A long-term (2-to-3-day) continuous discharge pump test was planned. The goal of this test was to estimate transmissivity and storage values. of the aquifer. Once transmissivity was calculated, hydraulic conductivity could be obtained. Immediately after the constant discharge test, recovery data was recorded.

IABLE 1. Well Design Information for VA Site(a)

\begin{tabular}{|c|c|c|c|c|}
\hline $\begin{array}{c}\text { We11 } \\
\text { Number }\end{array}$ & $\begin{array}{c}\text { Radius, } \\
\mathrm{ft} \\
\end{array}$ & $\begin{array}{c}\text { Diameter, } \\
\text { in. }\end{array}$ & $\begin{array}{c}\text { Screen } \\
\text { Interval, } \\
\mathrm{ft}\end{array}$ & $\begin{array}{c}\text { Depth, } \\
\mathrm{ft}\end{array}$ \\
\hline 1 & 950 & 2 & $192-232$ & 232 \\
\hline 2 & 150 & 2 & $170-210$ & 210 \\
\hline 3 & 65 & 2 & $175-215$ & 215 \\
\hline 4 & 40 & 2 & $180-220$ & 220 \\
\hline 5 & 950 & 2 & $208-248$ & 248 \\
\hline 6 & 62 & 2 & $135-175$ & 175 \\
\hline 7 & -- & 10 & $143-223$ & 223 \\
\hline
\end{tabular}

(a) All wells used 0.032 -in. slotted PVC screen. 


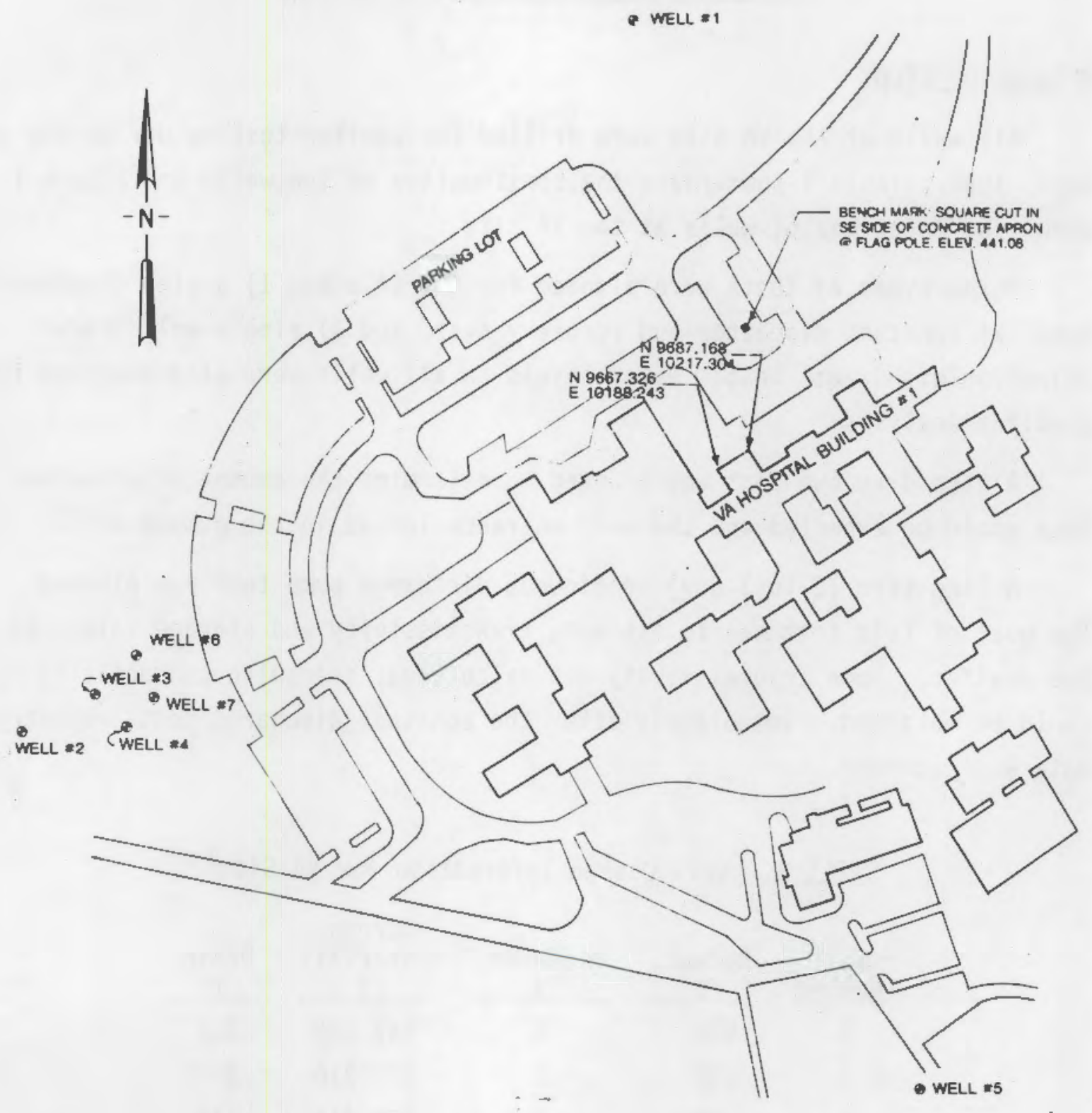

FIGURE 1. Locations of Wells at the VA Site

A single-well tracer injection/withdrawal drift and pumpback test was planned following full recovery from the aquifer pump test. The purpose of this test was to estimate ground-water velocity. A LiBr solution was mixed with aquifer water and injected into the pumping well. The residence time of the tracer in the aquifer was based on a velocity calculated from preliminary 
results of the aquifer test and gradient analyses. The tracer was removed four days later by pumping, and the concentration of the tracer was measured over the time of withdrawal.

\section{HYDROGEOLOGIC SETTING}

The hydrogeology of the setting can be described as comprising three elements: stratigraphy of the area, water levels and layers in the aquifer, and the hydraulic gradient and flow direction.

\section{Stratigraphy}

The stratigraphy in the vicinity of the VA site consists of unconsolidated sands, gravels, and clays of the Coker Formation (and/or Black Warrior River Valley deposits) which overlie the Pottsville Formation. The unconsolidated materials are about $220 \mathrm{ft}$ thick near the VA site. The upper 15 to $20 \mathrm{ft}$ of the materials consist mainly of red, sandy clay. The next approximately $125 \mathrm{ft}$ of the formation consist of undifferentiated layers of sand and clay. The lower approximately $80 \mathrm{ft}$ contain sands and gravels with scattered clay lenses present. The underlying Pottsville formation consists of shales and limestones with relatively low permeabilities compared to the unconsolidated sediments. The unconsolidated sediments offer the only unit in the vicinity that has potential for ATES use. Figure 2 shows stratigraphic diagrams for each well at the VA site. Appendix A contains geologic information from several drillers logs for the VA location.

\section{Aquifer Hydroqeology}

Undifferentiated sands and gravels overlying the Pottsville formation comprise the major aquifer in the vicinity of the site. Saturated thickness of the aquifer is approximately $75 \mathrm{ft}$. The depth to water at the VA site is about $145 \mathrm{ft}$ for wells 2, 3, 4, 6, and 7. Depth to water at wells 1 and 5 is about $165 \mathrm{ft}$ due to their topographically higher location. Results of this study indicate that clay lenses beneath the static water Jevel may be acting as locally confining or semi-confining layers for wells $2,3,4$, and 7 . We1l 6 shows no clay lenses below the static water level and appears to be 


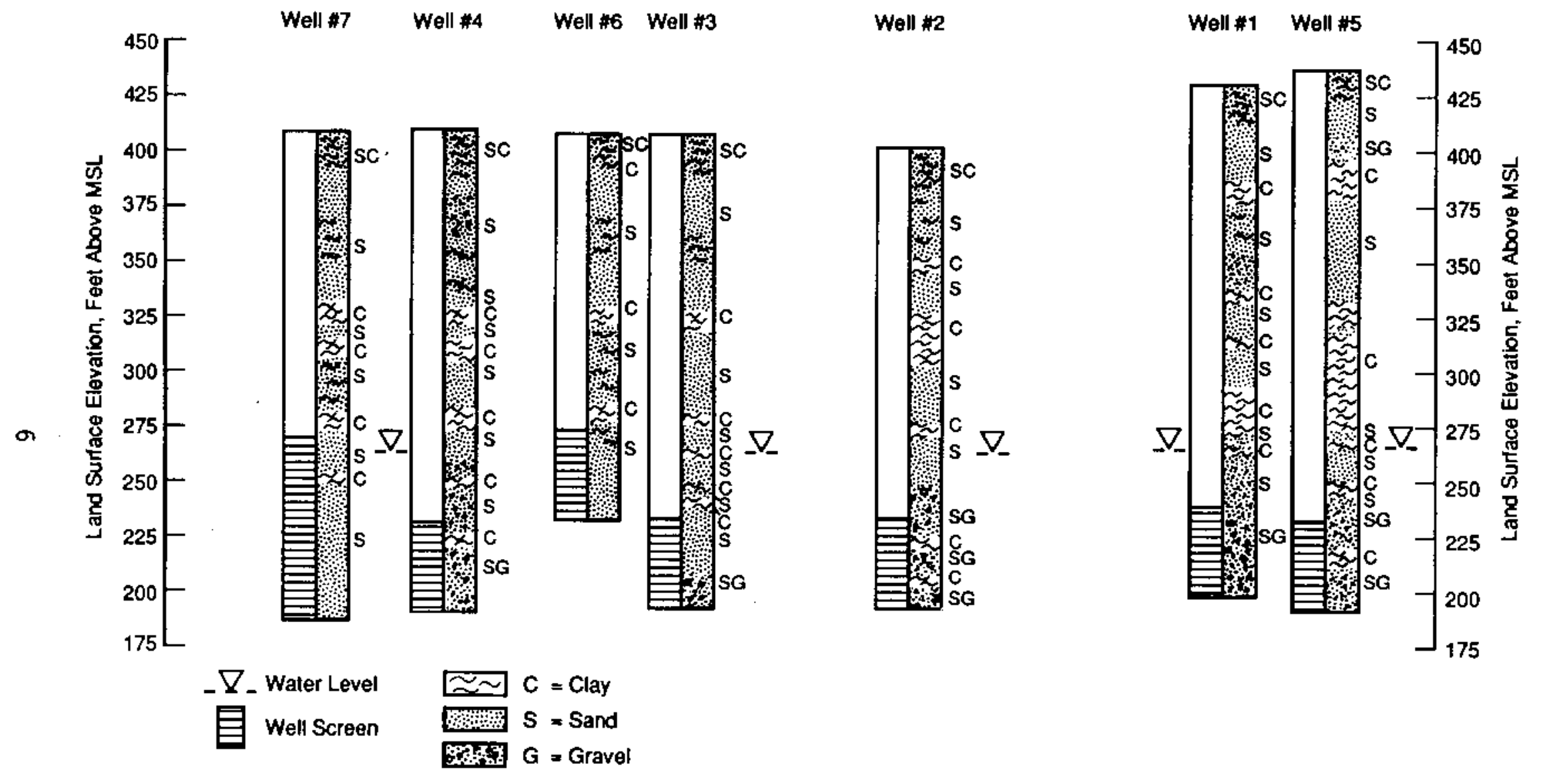

FIGURE 2. Stratigraphic Diagram of Wells at the VA Site 
unconfined. A relatively thick clay layer is present at or near the static water leve 1 in wells 1 and 5 , indicating possible confining conditions at these locations.

Hydraulic Gradient and Flow Direction

Water levels were measured in all wells to determine the direction and magnitude of the hydraulic gradient. Table 2 lists data from these measurements.

Ground-water flow direction at the VA site is generally towards the southwest. Magnitude of the gradient is approximately $2.5 \times 10^{-3}$ to $3 \times 10^{-3} \mathrm{ft} / \mathrm{ft}$. Figure 3 shows a ground-water map of the VA site for water levels measured in wells $1,2,3,4$, and 5 on May 24, 1989.

TABLE 2. Casing Elevations, Depth-to-Water Measurements, and Water-Level Elevations for Wells at the VA Site

\begin{tabular}{|c|c|c|c|c|}
\hline $\begin{array}{l}\text { Well } \\
\text { Number }\end{array}$ & $\begin{array}{l}\text { Casing } \\
\text { Elevation, } \mathrm{ft}\end{array}$ & $\begin{array}{c}\text { Date of } \\
\text { Measurement }\end{array}$ & $\begin{array}{l}\text { Depth to } \\
\text { Water, ft }\end{array}$ & $\begin{array}{l}\text { Water Level } \\
\text { Elevation, } \mathrm{ft}\end{array}$ \\
\hline 1 & 429.10 & $\begin{array}{l}05 / 24 / 89 \\
06 / 20 / 89 \\
06 / 21 / 89\end{array}$ & $\begin{array}{l}161.16 \\
161.22 \\
161.29\end{array}$ & $\begin{array}{l}267.94 \\
267.88 \\
267.81\end{array}$ \\
\hline 2 & 403.69 & $\begin{array}{l}05 / 24 / 89 \\
06 / 20 / 89 \\
06 / 21 / 89\end{array}$ & $\begin{array}{l}138.56 \\
138.44 \\
138.48\end{array}$ & $\begin{array}{l}265.13 \\
265.25 \\
265.21\end{array}$ \\
\hline 3 & 407.99 & $\begin{array}{l}05 / 24 / 89 \\
06 / 20 / 89 \\
06 / 21 / 89\end{array}$ & $\begin{array}{l}142.71 \\
142.75 \\
142.81\end{array}$ & $\begin{array}{l}265.28 \\
265.24 \\
265.18\end{array}$ \\
\hline 4 & 410.32 & $\begin{array}{l}05 / 24 / 89 \\
06 / 20 / 89 \\
06 / 21 / 89\end{array}$ & $\begin{array}{l}144.98 \\
144.85 \\
144.93\end{array}$ & $\begin{array}{l}265.34 \\
265.47 \\
265.39\end{array}$ \\
\hline 5 & 436.91 & $\begin{array}{l}05 / 24 / 89 \\
06 / 20 / 89 \\
06 / 21 / 89\end{array}$ & $\begin{array}{l}169.42 \\
169.30 \\
169.36\end{array}$ & $\begin{array}{l}267.49 \\
267.61 \\
267.55\end{array}$ \\
\hline 6 & 410.17 & $\begin{array}{l}06 / 20 / 89 \\
06 / 21 / 89\end{array}$ & $\begin{array}{l}143.80 \\
143.49\end{array}$ & $\begin{array}{l}266.37 \\
266.68\end{array}$ \\
\hline 7 & 414.02 & $06 / 20 / 89$ & 148.44 & 265.58 \\
\hline
\end{tabular}




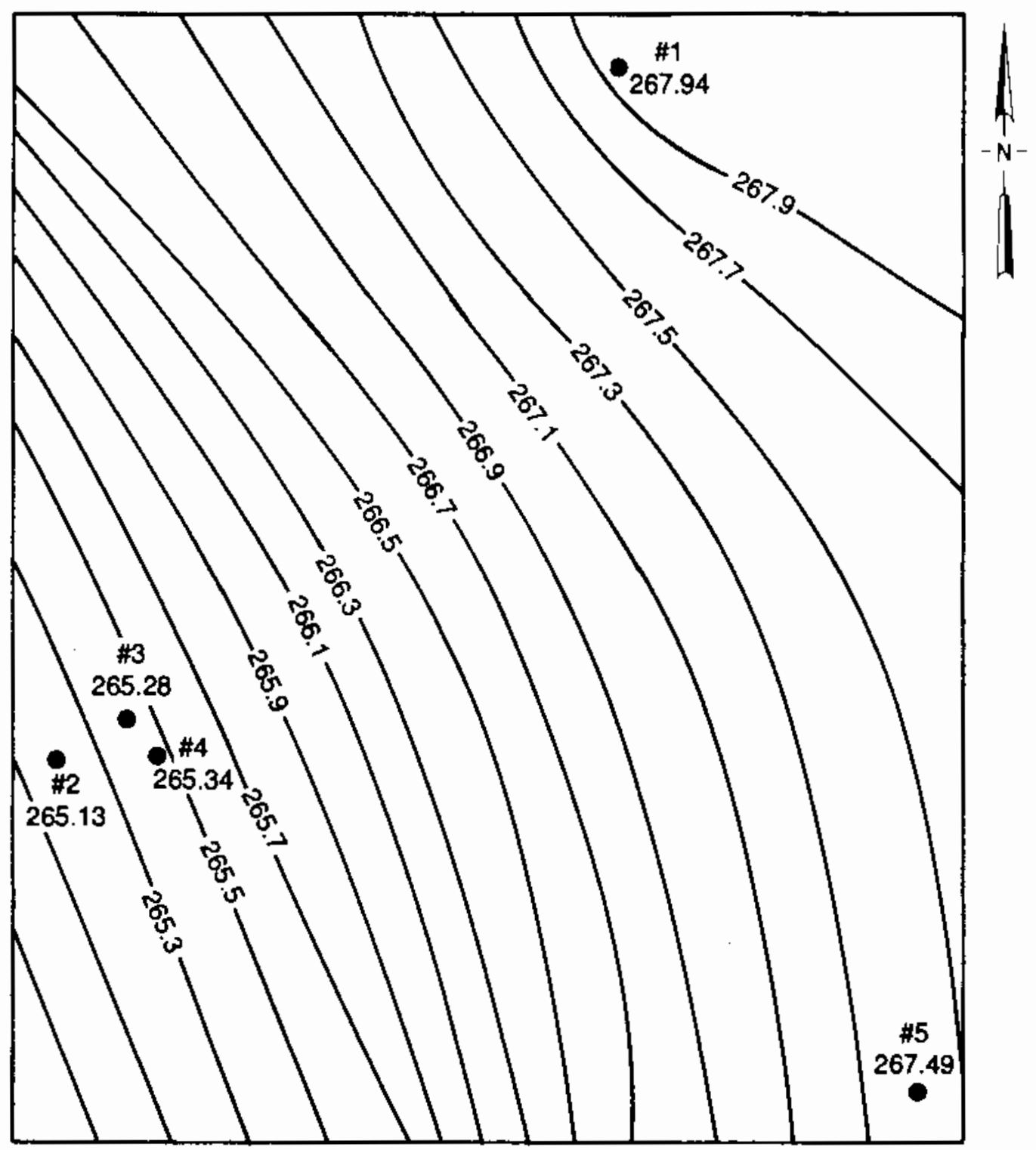

FIGURE 3. Water Table Elevation (ft) Map of the VA Site, Measured Measured May 24, 1989. Dot represents well locations. 


\section{IESTS AND RESULTS}

\section{STEP DRAWDOWN TEST}

A step drawdown test was conducted from $1200 \mathrm{hr}$ to $1652 \mathrm{hr}$ on June 20, 1989. We11 7 was the pumping we11, and the discharge rate was measured using an in-line pitot tube. Discharge was also measured by timing the discharge into a 26-qt pail. Steps of $60,120,180$, and 230 gal1ons per minute (gpm) were originally planned for the test. Occasional malfunction of the pitot tube during the test warranted use of the 26-qt pail for several discharge measurements. Using the pail measurements, steps of $90,140,200$, and $234 \mathrm{gpm}$ were obtained. A 50-psi transducer was placed in pump well 7 to measure drawdown. Ten-psi transducers were placed in wells 6 and 3 to measure responses to pumping in the vicinity of the pump well.

\section{Method of Analysis}

The Jacob method of analysis (Todd 1980) was used to estimate values for the aquifer constant (B) and the well loss constant (C). A graph of drawdown/discharge versus discharge gives the well loss constant (slope) and the aquifer constant (intercept). Drawdown in the well due to entrance losses is then calculated using the equation

$$
S=C Q^{2}
$$

where $s$ is the we 11 loss in $\mathrm{ft}, \mathrm{C}$ is the well loss constant, and $Q$ is the discharge during the constant discharge test. Appendix B contains graphs of the step drawdown analysis.

\section{Data Discussion}

A value of $7.1 \times 10^{-3} \mathrm{~min}^{2} / \mathrm{ft}^{5}\left(2.69 \mathrm{~min}^{2} / \mathrm{m}^{5}\right)$ was calculated for the well loss constant in pump well 7. This value suggests severe clogging or improper well design (Todd 1980.). Using a constant discharge value of $235 \mathrm{gpm}$, the drawdown due to well loss was approximately $7 \mathrm{ft}$. Pump we11 7 recovered approximately $90 \%$ within 3 minutes after turning off the pump, also indicating an inefficient well. 


\section{CONSTANT DISCHARGE AND RECOVERY TESTS}

A constant discharge pumping test was conducted from Apri1 21 at $1115 \mathrm{hr}$ to Apri1 23 at $1115 \mathrm{hr}$ (48 hours). The discharge rate was measured at approximately $230 \mathrm{gpm}$ using an in-line pitot tube. Timing the discharge into a 60-gallon steel drum gave an average value of $235 \mathrm{gpm}$, which was used in transmissivity and storage calculations. Discharged water flowed across the VA grounds into a nearby storm sewer.

Drawdown and recovery water-level data were collected in wells 3,4 , and 7 using 50-psi transducers and data loggers. Water-level data were collected in wells 2 and 6 using 10-psi transducers. Although a transducer had been set in well l, difficulties with the data logger resulted in no data being recorded. Water-level measurements in all wells were also made periodically with electric and steel tapes.

\section{Methods of Analysis}

The data exhibited responses that appeared to follow leaky confined (Boulton 1963) or delayed yield aquifer model responses. Type curves of these are given in Lohman (1972). Use of either set of type curves results in similar values of transmissivity, which is the primary aquifer property of concern.

Logarithmic plots of drawdown versus time were matched to type curves for delayed yield to obtain estimates of transmissivity and storage.

Analysis of recovery data by the Cooper-Jacob method (Cooper and Jacob 1946) was used to estimate transmissivity. The Theis recovery method was a]so used to obtain estimates of transmissivity and storage using log-log curve-matching techniques with delayed-yield type curves.

Data Discussion and Analysis

Drawdown data from wells 2, 3, 4 and 7 are difficult to match completely to the Theis curve. Nearly all drawdown in these wells occurs within the first 2 minutes of pumping. This initial drawdown produces time/drawdown curves that are difficult to match for early times. Well 6 shows a much slower response to pumping. 
Recovery analysis using the Theis method gave the best fit to delayed yield and leaky confined type curves, including early times. This method is presumed to give the most valid estimates of transmissivity and storage. Appendix $C$ contains drawdown and recovery plots for the test at the VA site.

Data from the wells tested are discussed below.

\section{We11 2}

During the first 2 minutes of the pump test, aquifer response shows about $1.5 \mathrm{ft}$ of drawdown. A maximum of approximately $4 \mathrm{ft}$ of drawdown was reached at the end of the test.

Logarithmic curve matching of drawdown data resulted in a value of $1200 \mathrm{ft}^{2} /$ day for transmissivity and a storage value of $1.5 \times 10^{-4}$. Logarithmic recovery curve matching resulted in a value of $2400 \mathrm{ft}^{2} /$ day for transmissivity and a storage value of $1.5 \times 10^{-4}$. Cooper-Jacob analysis of recovery data gave a value of $3700 \mathrm{ft}^{2} /$ day for transmissivity.

\section{We11 3}

Drawdown in well 3 reached a maximum of approximately $5 \mathrm{ft}$ at the end of the pump test. Logarithmic curve matching of drawdown data resulted in a value of $900 \mathrm{ft}^{2} /$ day for transmissivity and a storage value of $4 \times 10^{-4}$. Logarithmic recovery curve matching gave a transmissivity value of $1600 \mathrm{ft}^{2} /$ day and a storage value of $3.5 \times 10^{-4}$. Cooper-Jacob analysis of recovery data resulted in a transmissivity value of $2600 \mathrm{ft}^{2} /$ day.

\section{$\underline{\text { We11 } 4}$}

Drawdown in well 4 reached a maximum of approximately $7 \mathrm{ft}$ at the end of the pump test. Logarithmic curve matching of drawdown data resulted in a value of $600 \mathrm{ft}^{2} /$ day for transmissivity and a storage value of $5 \times 10^{-4}$. Logarithmic recovery curve matching gave a transmissivity value of $1300 \mathrm{ft}^{2} /$ day and a storage value of $3.4 \times 10^{-4}$. Cooper-Jacob analysis of recovery data resulted in a transmissivity value of $2000 \mathrm{ft}^{2} /$ day.

\section{Wel1 6}

Drawdown in we 116 reached a maximum of approximately $1.5 \mathrm{ft}$ at the end of the pump test. Sharp increases in the water level at times of 
approximately 800 and 2000 minutes were probably caused by surface runoff entering the well during heavy rains.

Logarithmic curve matching of drawdown data resulted in a value of $6000 \mathrm{ft}^{2} /$ day for transmissivity and a storage value of $3 \times 10^{-2}$. Logarithmic recovery curve matching gave a transmissivity value of $9000 \mathrm{ft}^{2} / \mathrm{day}$ and a storage value of $4.5 \times 10^{-2}$. Cooper-Jacob analysis of recovery data resulted in a transmissivity value of $9900 \mathrm{ft}^{2} / \mathrm{day}$.

Transmissivity values for well 6 are considerably higher than the other wells. Storage values are indicative of unconfined conditions. We11 6 was drilled to a depth of $175 \mathrm{ft}$ (about $45 \mathrm{ft}$ higher in the formation than the surrounding wells), and drillers' logs show no clay layers at or below the static water level. Significantly less drawdown in well 6 suggests anisotropic and heterogeneous aquifer conditions.

\section{We11 7}

We11 7 shows $20 \mathrm{ft}$ of drawdown within the first 2 minutes of the test (13 ft due to aquifer loss and $7 \mathrm{ft}$ due to well 10ss). A maximum of approximately $25 \mathrm{ft}$ of drawdown occurred at the end of the pump test (18 ft corrected for well loss).

Logarithmic curve matching of drawdown data resulted in a value of $100 \mathrm{ft}^{2} /$ day for transmissivity. Logarithmic recovery curve matching gave a transmissivity value of $500 \mathrm{ft}^{2} /$ day. Cooper-Jacob analys is of recovery data resulted in a transmissivity value of $550 \mathrm{ft}^{2} /$ day. Drawdown analysis for wel1 7 was conducted using corrected drawdown values (subtracting the wel1 loss of $7 \mathrm{ft}$ from each drawdown data point).

\section{Summary of Test Analyses}

Using logarithmic recovery results, transmissivity ranged from 500 to $9000 \mathrm{ft}^{2} /$ day for wells 6 and 7 . However, a best estimate of transmissivity probably came from well 2. The effects of vertical flow in well 2 were likely minimal due to the wells distance from the pump well. A larger volume of aquifer material was also being tested compared to other wells closer to the pump well. Using the transmissivity value from well 2 , a 
representative value for hydraulic conductivity is approximately $32 \mathrm{ft} /$ day. A summary of test analysis is provided in Table 3.

\section{SINGLE-WELL TRACER TEST}

The tracer test was performed in the single-well drift and pumpback mode described by Leap and Kaplan (1988). Using this method, a tracer slug is injected into a test well, is allowed to drift for a period of time, and is retrieved by pumping. The velocity of ground-water flow is calculated as a function of the amount of time required to recover the tracer slug at a given pumping rate. Data analysis also requires an estimate of effective porosity.

The method of Leap and Kaplan was derived for confined aquifers, that is, no dewatering is accounted for in their formula. However, the test at the VA site was conducted using a pumpback rate of only $60 \mathrm{gpm}$, with a maximum estimated drawdown of about $5 \mathrm{ft}$ or about $10 \%$ of the aquifer thickness.

TABLE 3. Test Analyses Grouped by Method

\begin{tabular}{|c|c|c|}
\hline We11 & Transmissivity, $\mathrm{ft}^{2} /$ day & Storage value \\
\hline $\begin{array}{l}2 \\
3 \\
4 \\
6 \\
7\end{array}$ & $\begin{array}{c}\text { Logarithmic Drawdown } \\
\text { Curve Matching } \\
1200 \\
900 \\
600 \\
6000 \\
100\end{array}$ & $\begin{array}{r}1.5 \times 10^{-4} \\
4 \times 10^{-4} \\
5 \times 10^{-4} \\
3 \times 10^{-2} \\
\\
\cdots\end{array}$ \\
\hline $\begin{array}{l}2 \\
3 \\
4 \\
6 \\
7\end{array}$ & $\begin{array}{c}\text { Cooper-Jacob Semilog Recovery } \\
3700 \\
2600 \\
2000 \\
9900 \\
550\end{array}$ & $\begin{array}{l}-- \\
-- \\
-- \\
--\end{array}$ \\
\hline $\begin{array}{l}2 \\
3 \\
4 \\
6 \\
7\end{array}$ & $\begin{array}{l}\text { Logarithmic The is-Type } \\
\text { Recovery Curve Matching } \\
2400 \\
1600 \\
1300 \\
9000 \\
500\end{array}$ & $\begin{array}{r}1.5 \times 10^{-4} \\
3.5 \times 10^{-4} \\
3 \times 10^{-4} \\
4.5 \times 10^{-2} \\
-\ldots .\end{array}$ \\
\hline
\end{tabular}


The effect of this drawdown may be viewed as a small perturbation of effective porosity in the vicinity of the well bore during pumpback.

Leap and Kaplan describe a "velocity shadow" downgradient from the test we11, the effect of which is an apparent reduction of flow velocity near the we17. As drift time increases, the effect of the shadow decreases. The effect of the shadow is consistent with the fact that within the well bore the porosity is $100 \%$, and horizontal flow rate through the well will be smaller than through the sediments. Although the tracer slug will require extra time to be flushed from the well, that additional time increment will become negligible as drift time increases. Leap and Kaplan offer no method to compensate for the effect of a velocity shadow except to perform a series of tests using progressively longer drift times.

\section{Tracer Injection}

Ground water collected during previously conducted pumping tests was stored in six 55-gallon drums and was available for the tracer test at the test site. On July 11, 1989, approximately 42 grams of $\mathrm{LiBr}$ was added to each of the six drums to prepare the tracer solution. The solution in each drum was mixed by air injection. Untreated ground water and each of the treated drums was sampled for analysis.

Beginning at $1104 \mathrm{hr}$ on July 11 , the tracer solution was injected into the test well at a net rate of $4.0 \mathrm{gpm}$. Injection of the tracer was completed by $1202 \mathrm{hr}$. Total slug volume was estimated to be 319 gallons, which is approximately one standing bore volume of the well. Injection of the tracer was accomplished using a $12-\mathrm{V}$ battery-operated marine bilge pump (Mayfair Pro-line 600 Model 2260) connected to a 3/4-in. (ID) garden hose. Maximum flow rate of tracer into the well was $5.1 \mathrm{gpm}$.

Volume of the injected tracer was determined by measuring the drums and subtracting $2 \mathrm{in}$. from the drum height to allow for $1 \mathrm{in}$. of solution remaining at the bottom of each drum (the pump could not pick up less than about 1 -in. depth) and 1 in. at the top of each drum (which was incompletely filled). Calculations show that approximately 53.2 gallons from each drum were injected into the well. 


\section{Field Measurements}

A bromide-ion-selective electrode was available for monitoring the ground water during the pumpback phase of the test. The Corning bromide electrode (model no. 476128) was used in conjunction with an Orion double junction reference electrode (model no. 900200) and a portable Hach ${ }^{\circledR}$ (a) One $\mathrm{pH}$ Meter (model no. 43800-00). Outer filling solution for the reference electrode was $10 \% \mathrm{~K}_{3}$. The Hach meter was used in the millivolt mode, and it was necessary to splice both electrodes to a single BNC connector.

No ionic strength adjuster was used for bromide measurements, and the electrode was calibrated by spiking samples of the ground water with a high and low concentration bromide solution. The resulting calibration was

$$
C=10^{[(119.5-E) / 56.9]}
$$

where $C$ is bromide concentration in $\mathrm{mg} / \mathrm{L}$ and $\mathrm{E}$ is measured potential in millivolts.

On July 15 (4 days later) at $0834 \mathrm{hr}$, the test we 11 was pumped at a rate of $60 \mathrm{gpm}$, and field analysis for bromide was performed using the ionselective electrode. A1l samples were collected unpreserved in $125-\mathrm{mL}$ polyethylene bottles. Laboratory analyses of collected samples were intended to provide a check on the electrode readings; however, these analyses were inconclusive. Field data were therefore used for data analyses and interpretation.

Figure 4 shows the results of the field analysis. Field data showed that the center of mass of the slug was recovered after 34 minutes of pumping.

\section{GROUND-WATER VELOCITY}

The average ground-water velocity in the immediate vicinity of well 7 was calculated by analysis of the aquifer test results coupled with the

(a) Hach is a registered trademark of Hach Corporation, Loveland, Colorado. 


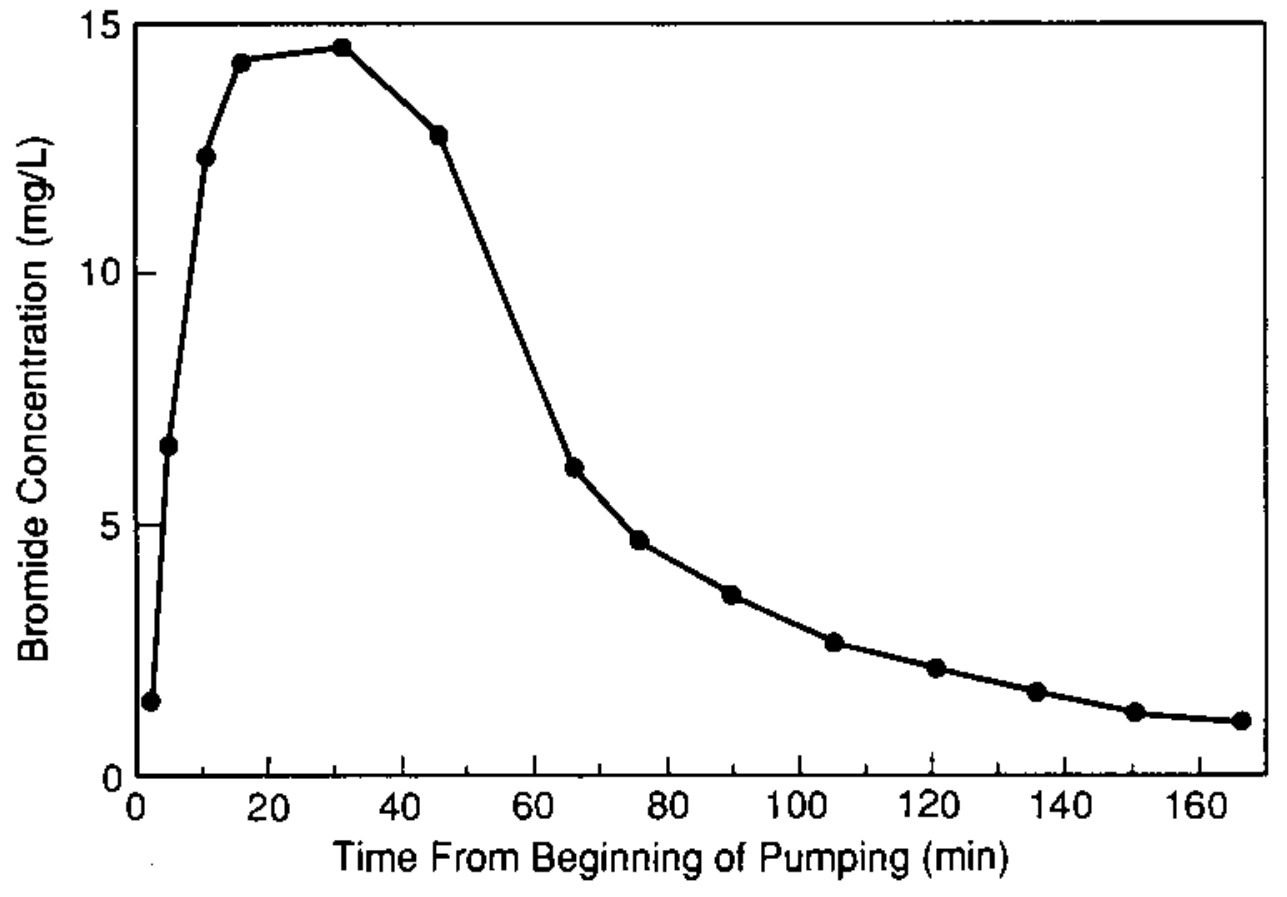

FIGURE 4. Concentration of Lithium Bromide Tracer Versus Time for the Pumpback Portion of the Tracer Test at the VA Site

hydraulic gradient and by analysis of the tracer test. Effective porosity was varied in both analyses to arrive at the velocity determinations. The calculated velocity based on hydraulic methods is proportional to the inverse of the effective porosity, while velocity calculated from the tracer test data is proportional to the square root of the effective porosity. Darcy's Law

The results of velocity calculations from the aquifer test are based on Darcy's Law as follows:

$$
V=(K \cdot I) / n
$$

where $V=$ average linear ground-water velocity

$K=$ hydraulic conductivity

$I=$ hydraulic gradient

$n=$ effective porosity 
Letting $K=32 \mathrm{ft} /$ day and $I=0.003$, velocities for a range of effective porosity, $n$, can be calculated. These are plotted in Figure 5 .

\section{Tracer Test}

The following formula offered by Leap and Kaplan was used to calculate advective ground-water velocity from the results of the tracer test:

$$
V=[1440 \cdot \sqrt{(t /(n \cdot b \cdot \pi)}] / T
$$

where $V=$ velocity in $\mathrm{ft} /$ day

$Q=$ pump discharge in cubic feet per minute (cfm)

$t=t$ ime in minutes from the start of pumping to recovery of the center of mass

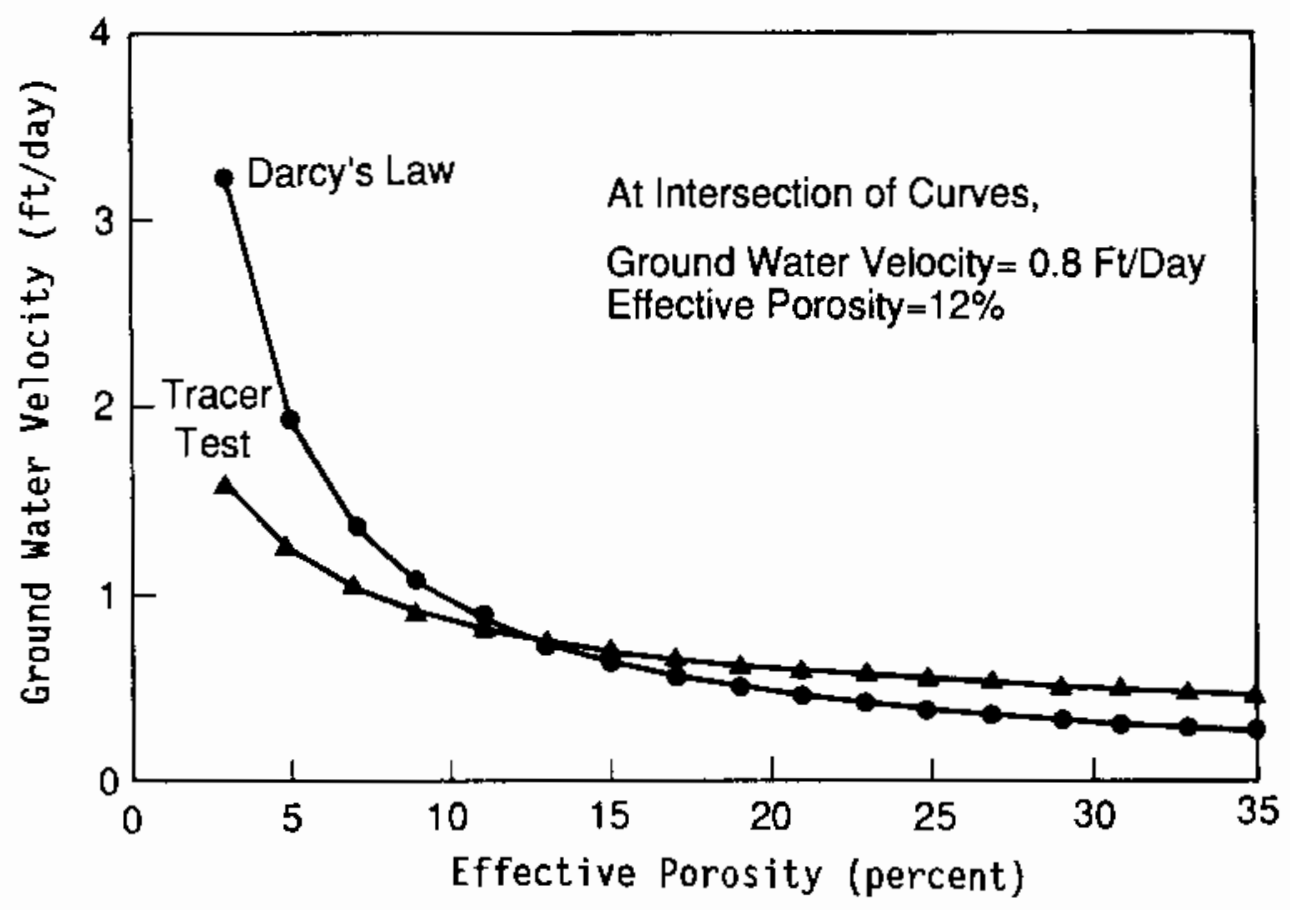

FIGURE 5. Plot of Velocity Versus Effective Porosity By Both the Tracer Test Method and Darcy's Law 


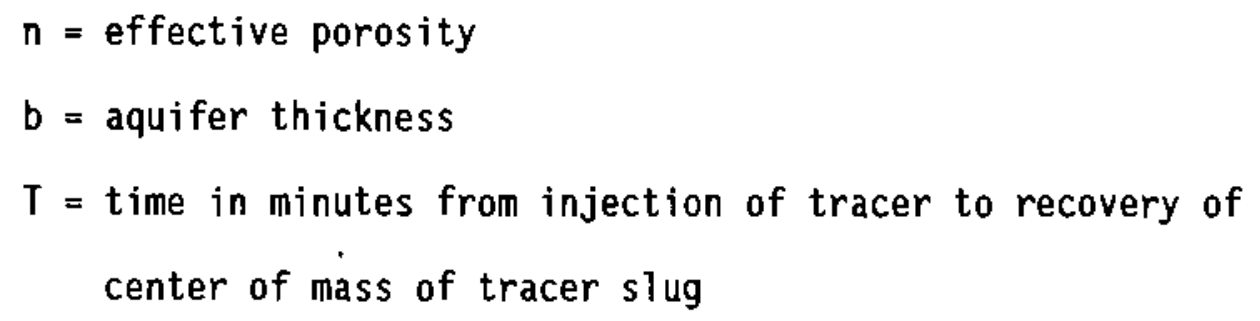

With values for all variables, velocities for a range of effective porosity, $n$, can be calculated. These also are plotted on Figure 5 .

\section{Simultaneous Analysis}

The values for velocity and effective porosity are taken from the point where the curves resulting from the above equations intersect. That is, the point of intersection of the curves represents the solution of two simultaneous equations in two unknowns. The intersection of these lines results in a ground-water velocity of approximately $0.8 \mathrm{ft} /$ day and an effective porosity of approximately $12 \%$. 


\section{CONCLUSIONS}

Results obtained from the aquifer pumping and tracer tests at the VA site provide quantitative values of aquifer properties. The transmissivity in the vicinity of well 2 is approximately $2400 \mathrm{ft}^{2} / \mathrm{day}$. The average hydraulic conductivity is assumed to be approximately $32 \mathrm{ft} /$ day. Groundwater flow at the $V A$ site is generally toward the southwest with a gradient of approximately $3 \times 10^{-3} \mathrm{ft} / \mathrm{ft}$. Results of the tracer and pump tests were used simultaneously to determine ground-water velocity to be approximately $0.8 \mathrm{ft} /$ day. An estimate of effective porosity is about $12 \%$ using the same method. Limitations of the analyses result from the complex geologic setting. Differences in responses to pumping in wells 3 and 6 (approximately the same radial distance from the pump we11) suggest aquifer anisotropy and heterogeneity. Aquifer heterogeneities may cause varying hydraulic conductivity values through the vertical profile, thus varying velocities, Clay lenses located in the lower saturated sediments of the aquifer may be acting locally as a semi-confining layer. 



\section{REFERENCES}

Boulton, N. S. 1963. "Analysis of Data from Non-Equilibrium Pumping Tests Allowing for Delayed Yield from Storage." Inst. Civil Engineers Proc. $26: 469-482$.

Cooper, H. H., Jr. 1963. "Type Curves for Nonsteady Radial Flow in an Infinite Leaky Artesian Aquifer." In Shortcuts and Special Problems in Aquifer Tests, ed. R. Bental, pp. C48-C55. Water-Supply Paper 1545-C, U.S. Geological Survey, Washington, D.C.

Cooper, H. H., Jr., and C. E. Jacob. 1946. "A Generalized Graphical Method for Evaluating Formation Constants and Summarizing Well-Field History." Am. Geophys. Union Trans. 27(4):526-534.

Leap, D. I., and P. G. Kaplan. 1988. "A Single-We11 Tracing Method for Estimating Regional Advective Velocity in a Confined Aquifer: Theory and Preliminary Laboratory Verification." Water Resources Research $24(7): 993-998$.

Lohman, S. W. 1972. Ground-Water Hydraulics. Professional Paper 708, U.S. Geological Survey, Washington, D.C.

Todd, D.K. 1980. Groundwater Hydrology. 2nd ed. John Wiley, New York. 


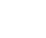




\section{APPENDIX A}

DRILLERS' LOGS FOR WELLS DRILLED IN THE

VICINITY OF THE VETERANS ADMINISTRATION

FACILITY, TUSCALOOSA, ALABAMA 


\section{DRILLERS' LOGS FOR WELLS DRILLED IN THE VICINITY OF THE VETERANS ADMINISTRATION \\ FACILITY, TUSCALOOSA, ALABAMA}

\section{IABLE A.1. We11 1}

\section{Depth Below Land

Surface, ft

$0-18$

$18-44$

44-55

$55-75$

$75-90$

$90-93$

$93-98$

98-115

$115-120$

$120-138$

$138-161$

$161-164$

$164-168$

$168-195$

$195-232$

232

Lithology
red sandy clay
sand
clay
sand w/clay streaks
sand, coarse
sand
clay
sand
clay
sand
sticky clay
sand
clay
coarse sand
coarse sand and small gravel
to Pottsville

Rock at $44,55,63$ and 161 feet $192 \mathrm{ft}, 2 \mathrm{in}$. PVC; $40 \mathrm{ft}, 2$ in. PVC screen 0.032 Date: 5-16-89

Well at front of building 
IABLE A.2. We11 2

Depth Below Land

Surface, ft

$0-18$

$18-45$

45- 50

$50-53$

$53-75$

$75-90$

90-96

96-105

$105-123$

123-132

$132-150$

$150-175$

$175-178$

$178-180$

$180-192$

$192-194$

195-210

210

Lithology
red sandy clay
sand with clay deposits
sand
clay
sand
sticky clay
clay
fine sand
sand
clay
sand
coarse sand and small gravel
clay
sand
sand and pea gravel
clay and pea gravel
sand and
Pottsville

Rock at 70 and 74 feet

$170 \mathrm{ft}, 2$ in. PVC; $40 \mathrm{ft}, 2$ in. screen 0.032

Date: $5-15-89$

$60 \mathrm{ft}$ from production well 
IABLE A.3. Well 3

Depth Below Land

Surface, $\mathrm{ft}$

$0-20$

20-45

$45-60$

$60-80$

$80-88$

$88-125$

$125-133$

$133-140$

$140-143$

$143-157$

$157-158$

158-161

161-162

$162-195$

195-215

Lithology

red sandy clay

sand

sand with clay streaks

sand

clay

sand

clay

sand

clay

sand

clay

sand

clay

sand

sand and pea gravel

$215 \mathrm{ft}$ bottom of sand, top of Pottsville

Rock at 27,69, 88, 134 and 215 feet

$175 \mathrm{ft}, 2$ in. PVC; $40 \mathrm{ft}, 2$ in. PVC 0.032 screen 
IABLE A.4. Well 4

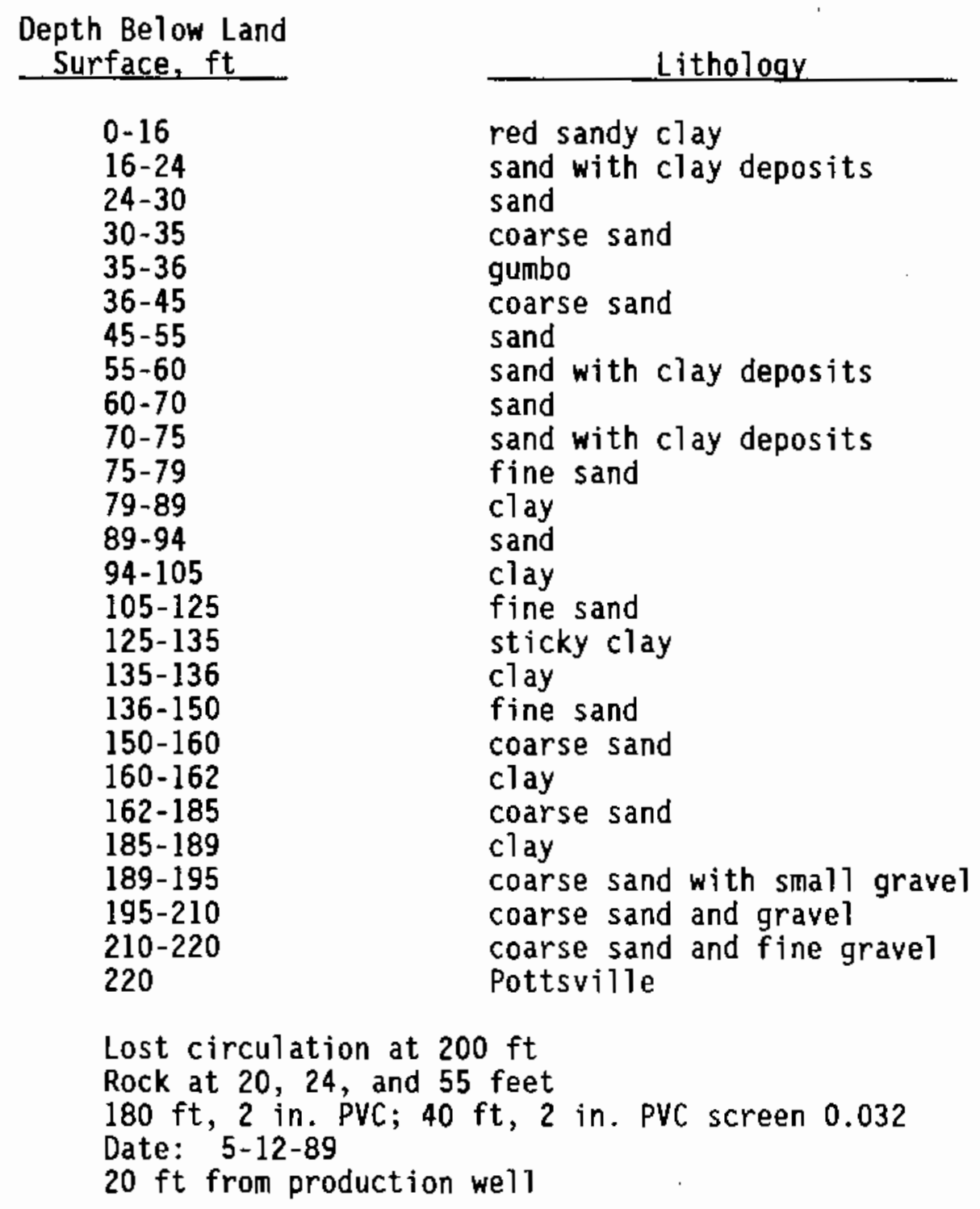


IABLE A.5. We11 5

\begin{tabular}{ll}
$\begin{array}{c}\text { Depth Below Land } \\
\text { Surface, ft }\end{array}$ & Lithology \\
\cline { 1 - 1 } $0-17$ & red sandy clay \\
$17-30$ & sand \\
$30-40$ & sand and gravel \\
$40-58$ & clay \\
$58-73$ & fine sand \\
$73-87$ & sand with clay streaks \\
$87-104$ & sand \\
$104-115$ & sticky clay \\
$115-117$ & sand \\
$117-164$ & sticky clay \\
$164-168$ & sand \\
$168-172$ & clay \\
$172-188$ & sand \\
$188-191$ & clay \\
$191-195$ & sand \\
$195-219$ & sand and small grave 1 \\
$219-223$ & clay \\
$223-248$ & sand and gravel \\
248 & Pottsville \\
Rock at $40,73,87,92$, and $164 \mathrm{ft}$ \\
$208 \mathrm{ft}, 2$ in. PVC; $40 \mathrm{ft}, 2$ in. PVC screen 0.032 \\
Date $5-17-89$ \\
Wel1 at back of building
\end{tabular}


IABLE A.6. We11 6

Depth Below Land

Surface, $\mathrm{ft}$

$0-18$

$18-35$

$35-62$

$62-79$

$79-85$

$85-124$

124-130

130-142

$142-175$

Lithology

sandy red clay

sand

sand with clay streaks

sand

clay

sand with clay streaks

clay

sand with clay streaks

sand

$135 \mathrm{ft}, 2$ in. PVC pipe; $40 \mathrm{ft}, 2$ in. 0.032

PVC screen;

Date: $6-14-89$

$50 \mathrm{ft}$ from production we 11

TABLE A.7. Wel1 7

Depth Below Land

Surface, $\mathrm{ft}$

$0-20$

20-37

$37-63$

73-78

$78-89$

$89-95$

95-102

$102-127$

$127-134$

$134-161$

161-162

162-223

Lithology

sand red clay

sand

sand with clay streaks

sand

clay

sand

c] ay

sand with clay streaks

clay

sand

clay

sand

$143 \mathrm{ft}, 10 \mathrm{in}$. PVC casing; $80 \mathrm{ft}, 20 \mathrm{in.} P V C$ screen 0.032

Date: $6-7-89$ 
APPENDIX B

STEP DRAWDOWN ANALYSIS 


\section{APPENDIX B}

\section{STEP DRAWDOWN ANALYSIS}

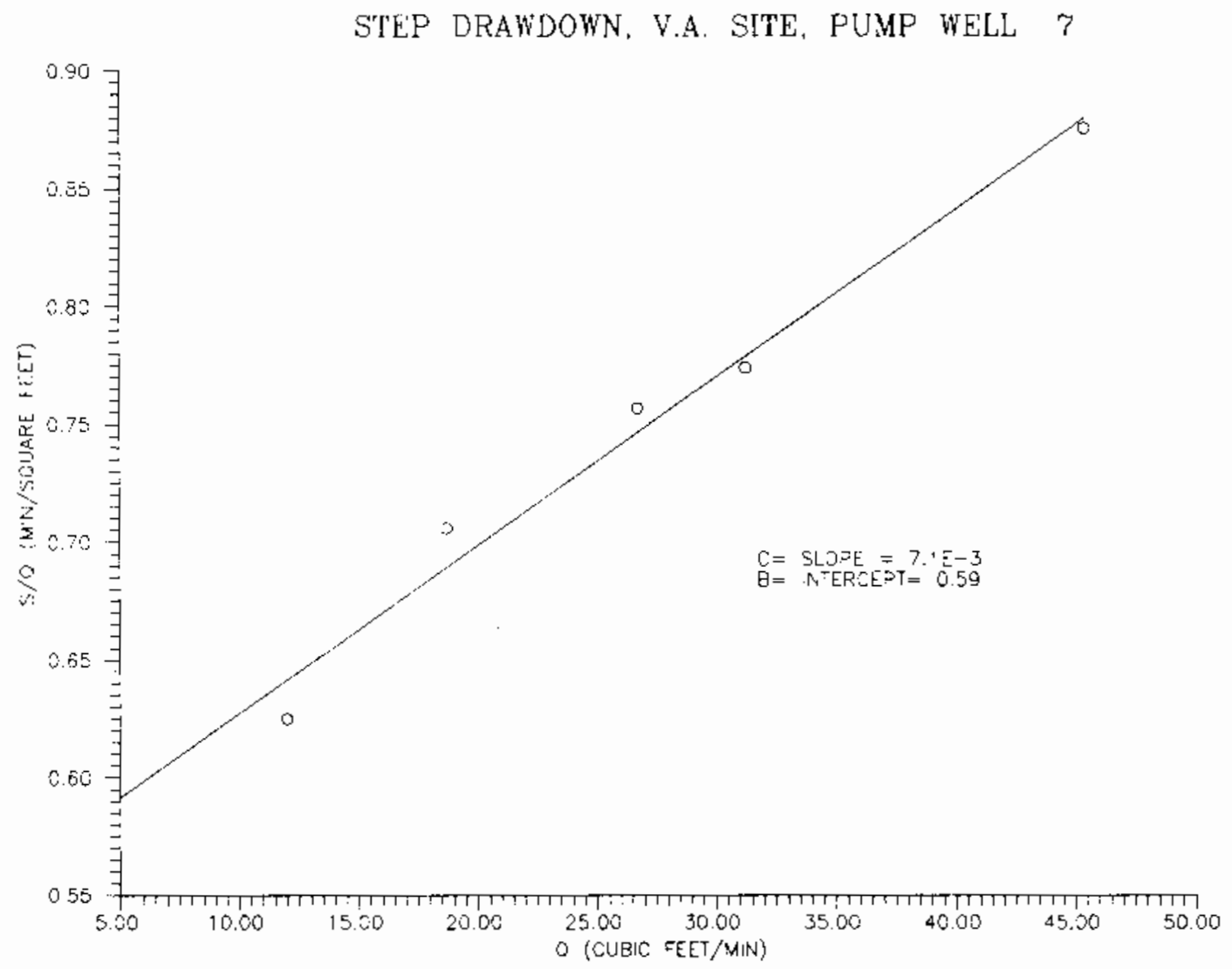

FIGURE B.1. Step Drawdown Analysis for Well 7

B. 1 
STEP DRAWDOWN, V.A. SITE, WELLS 3, 6, AND 7

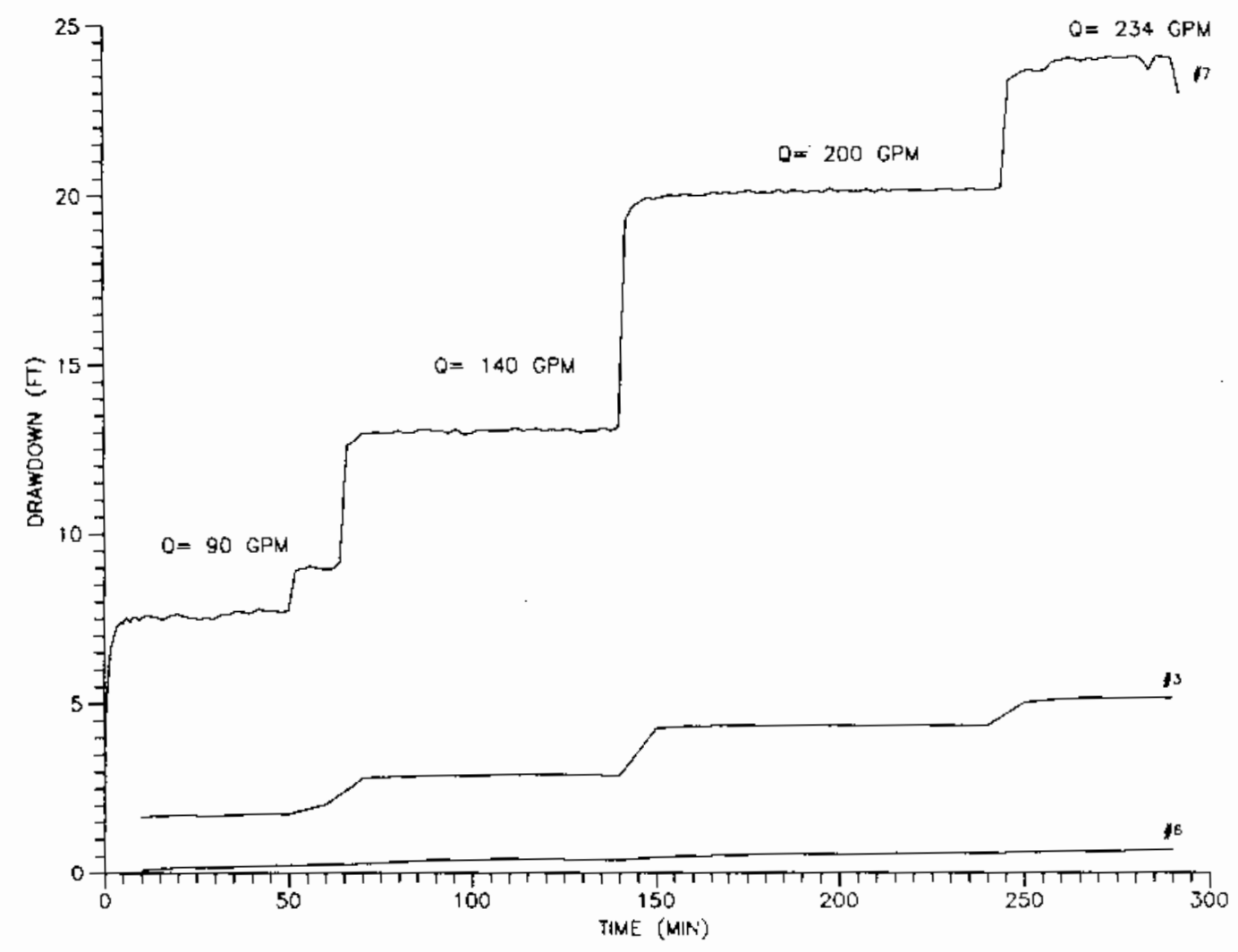

FIGURE B.2. Responses to Pumping Rates in Wells 3, 6, and 7 During Step Drawdown Test 
APPENDIX C

PUMP TEST DATA 
APPENDIX C

PUMP TEST DATA

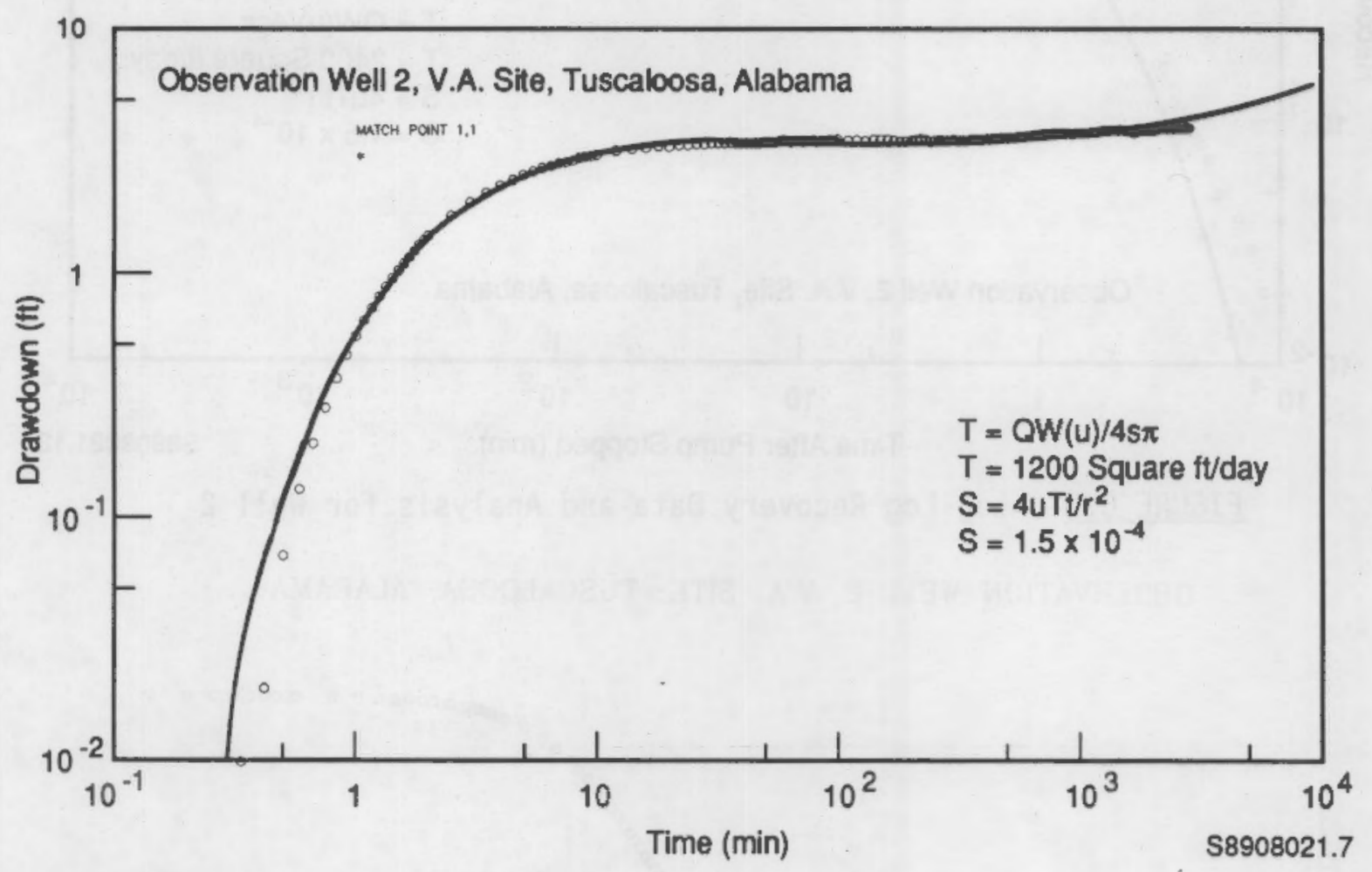

FIGURE C.1. Drawdown Data and Analysis for Well 2

C.1 


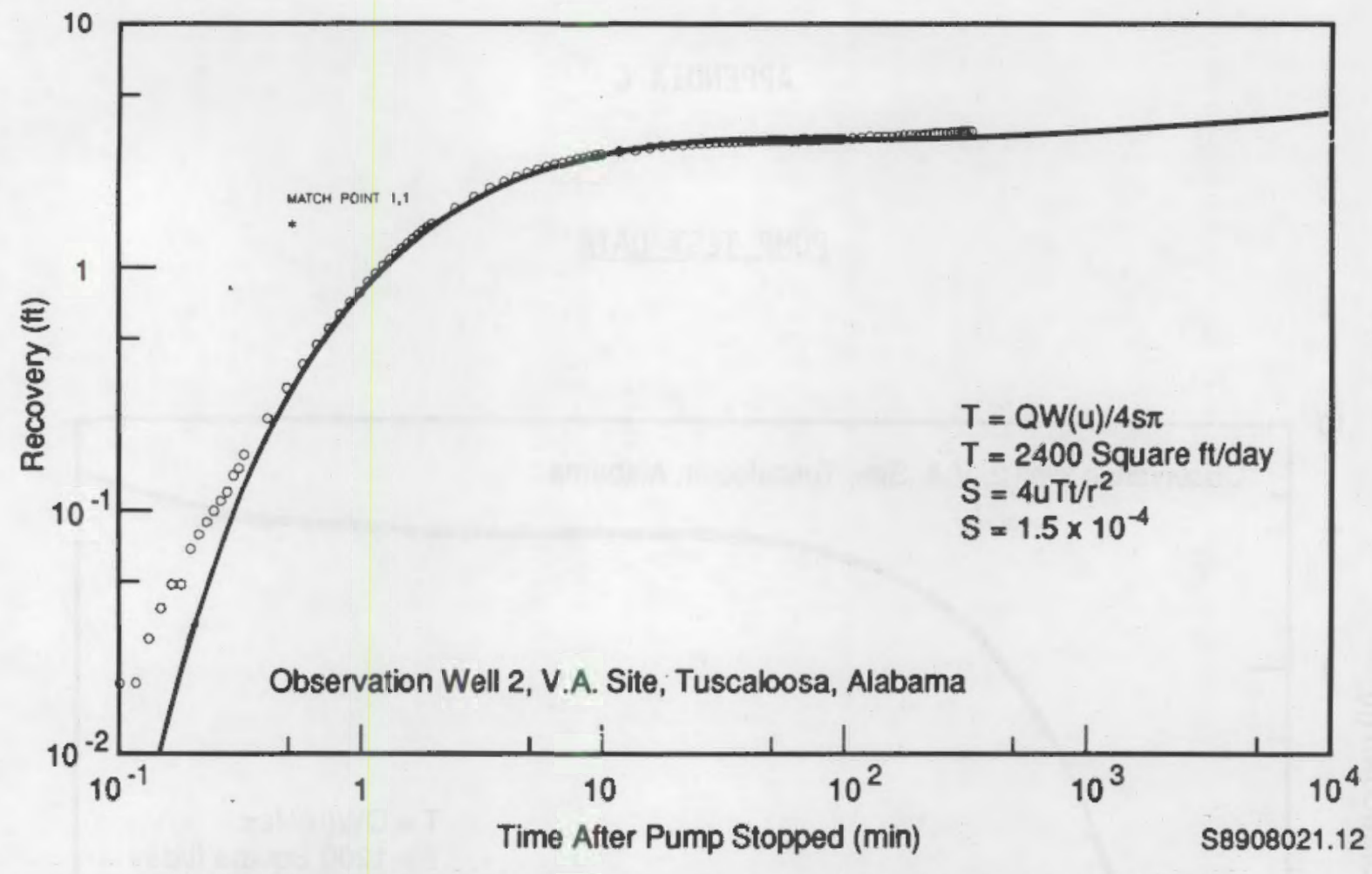

FIGURE C.2. Log-Log Recovery Data and Analysis for Well 2

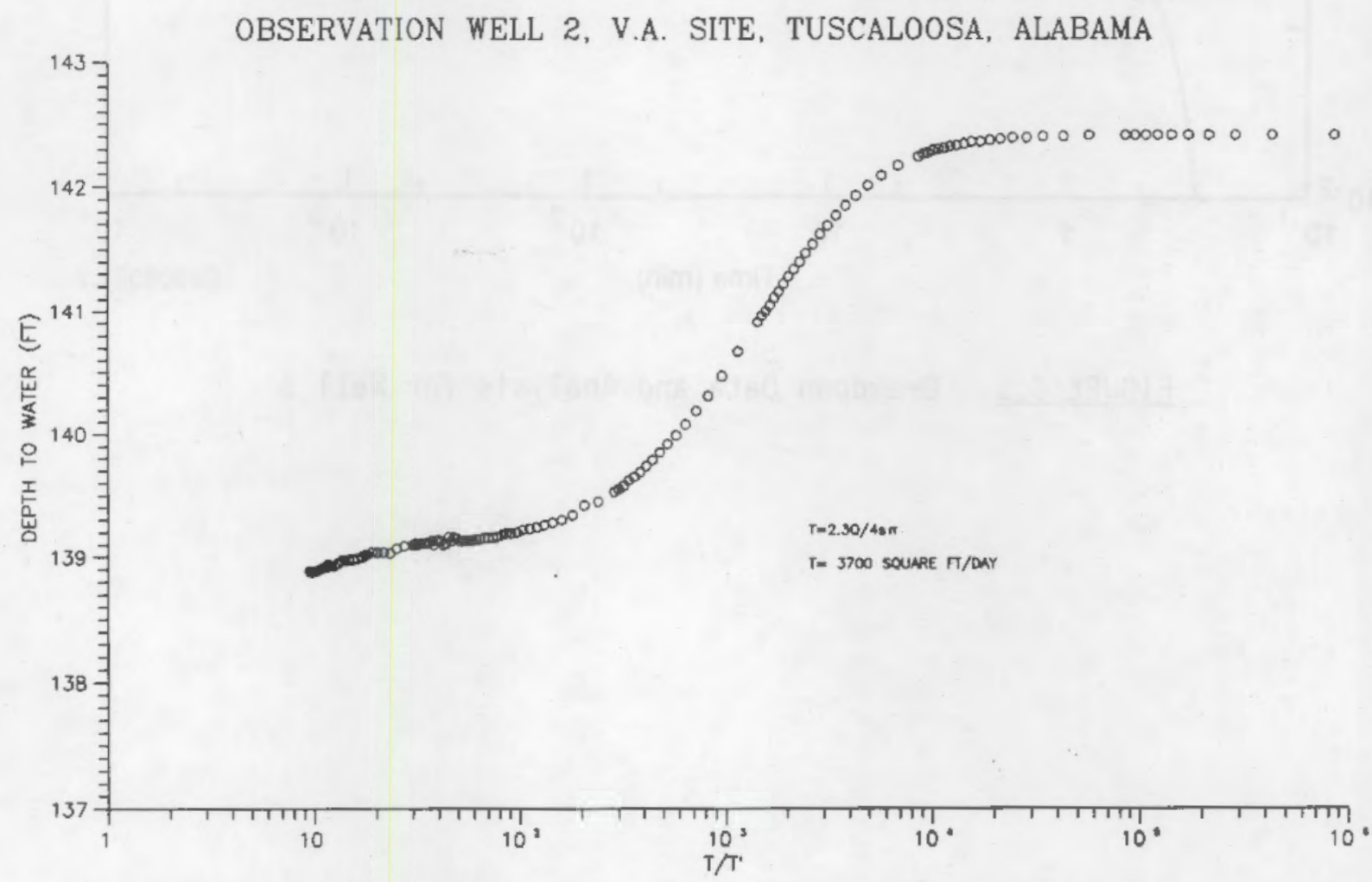

FIGURE C.3. Cooper-Jacob Semilog Recovery Data and Analysis for Well 2

C.2 


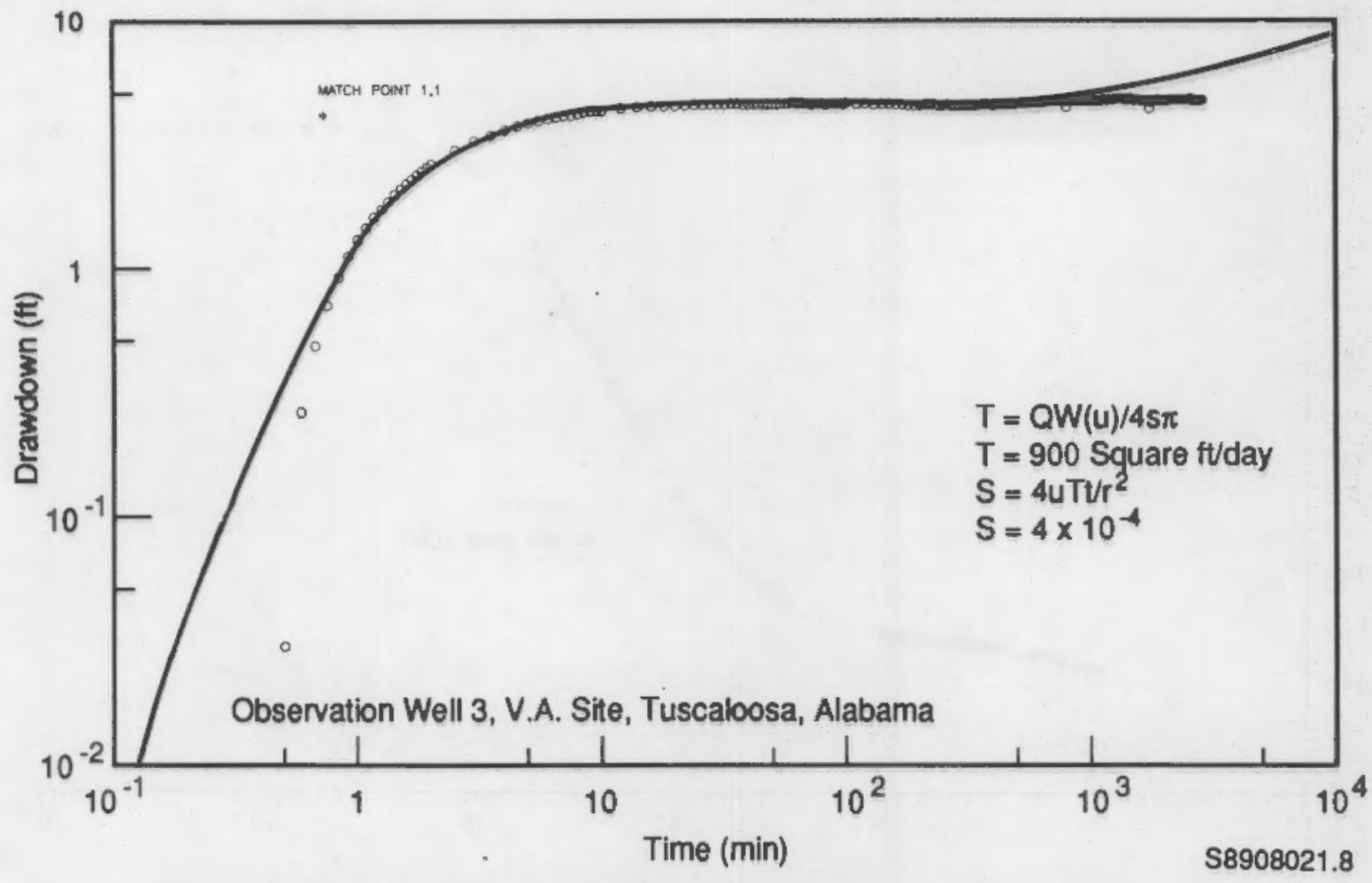

FIGURE C.4. Drawdown Data and Analysis for Well 3

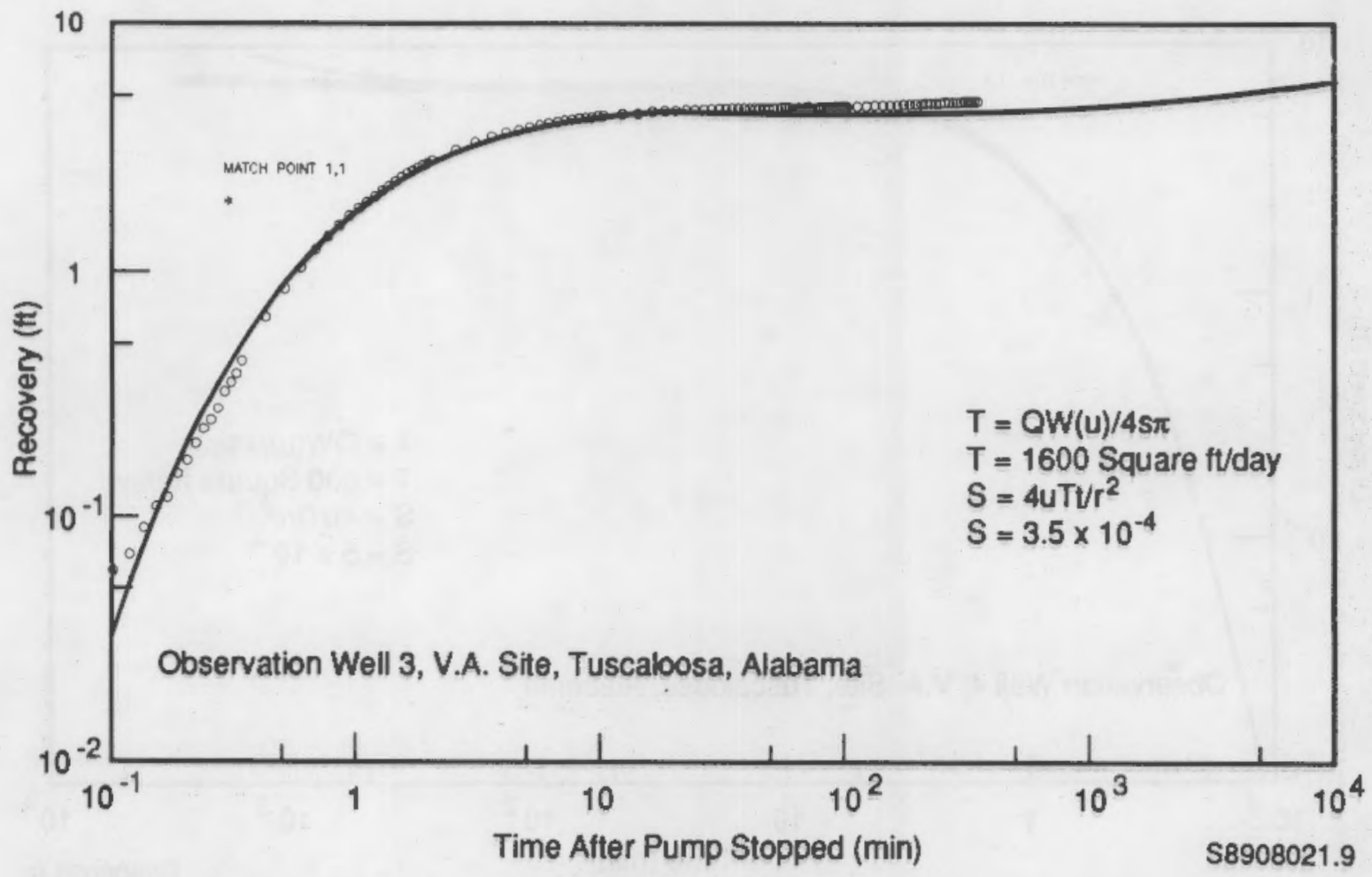

FIGURE C.5. Log-Log Recovery Data and Analysis for Well 3 
OBSERVATION WELL 3, V.A. SITE, TUSCALOOSA, ALABAMA

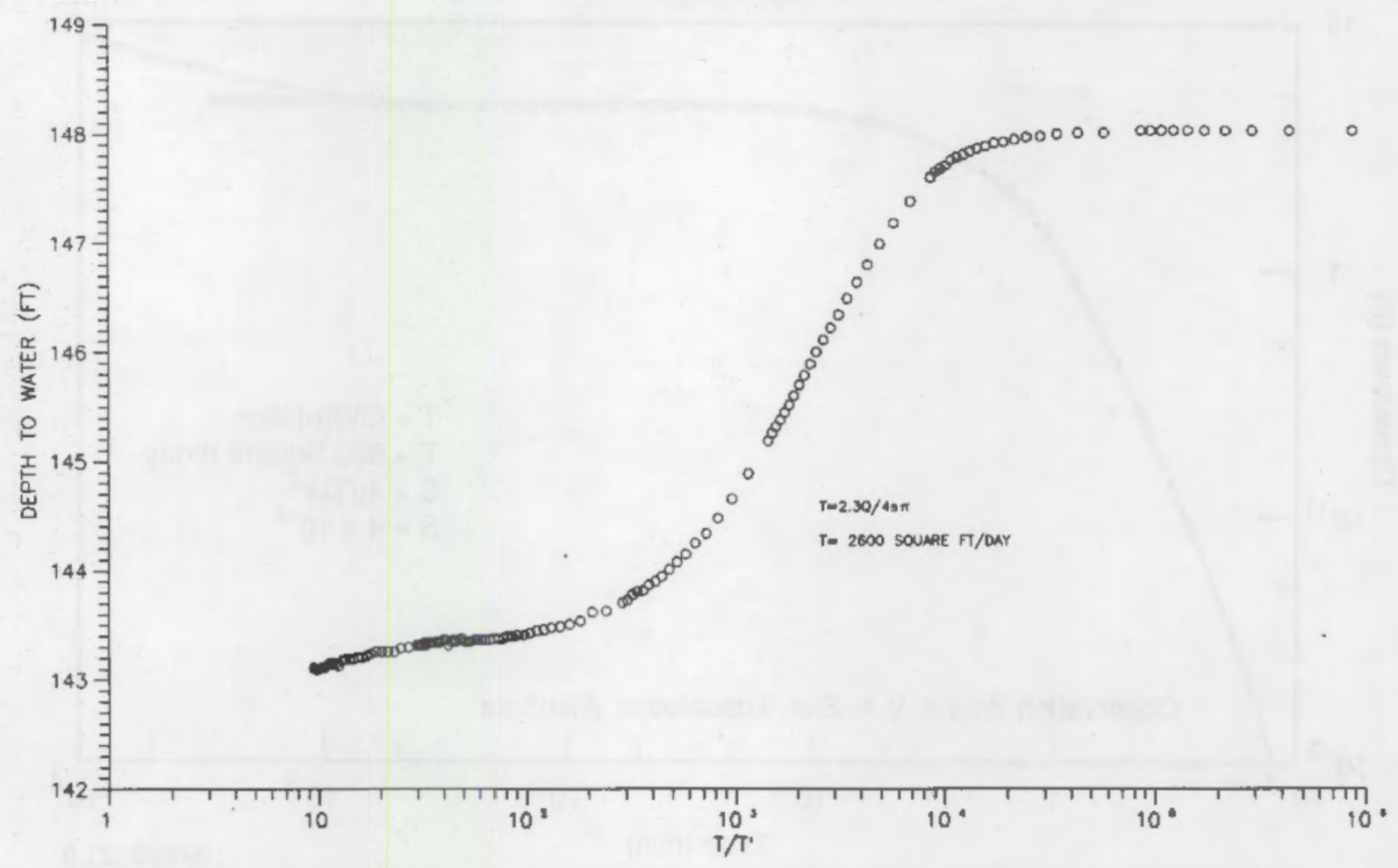

FIGURE C.6. Cooper-Jacob Semilog Recovery Data and Analysis for Well 3

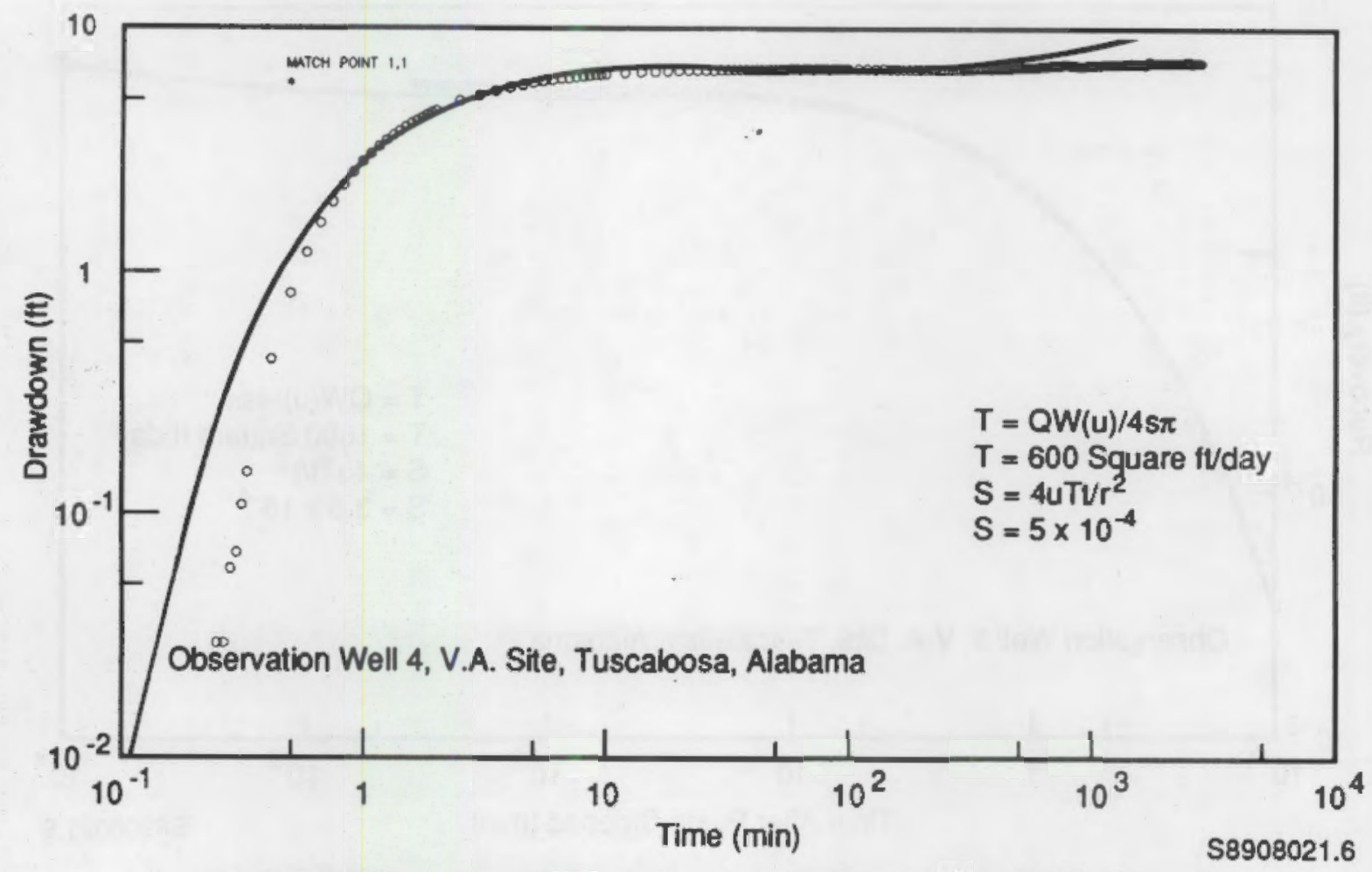

FIGURE C.7. Drawdown Data and Analysis for Well 4

$$
\text { C. } 4
$$




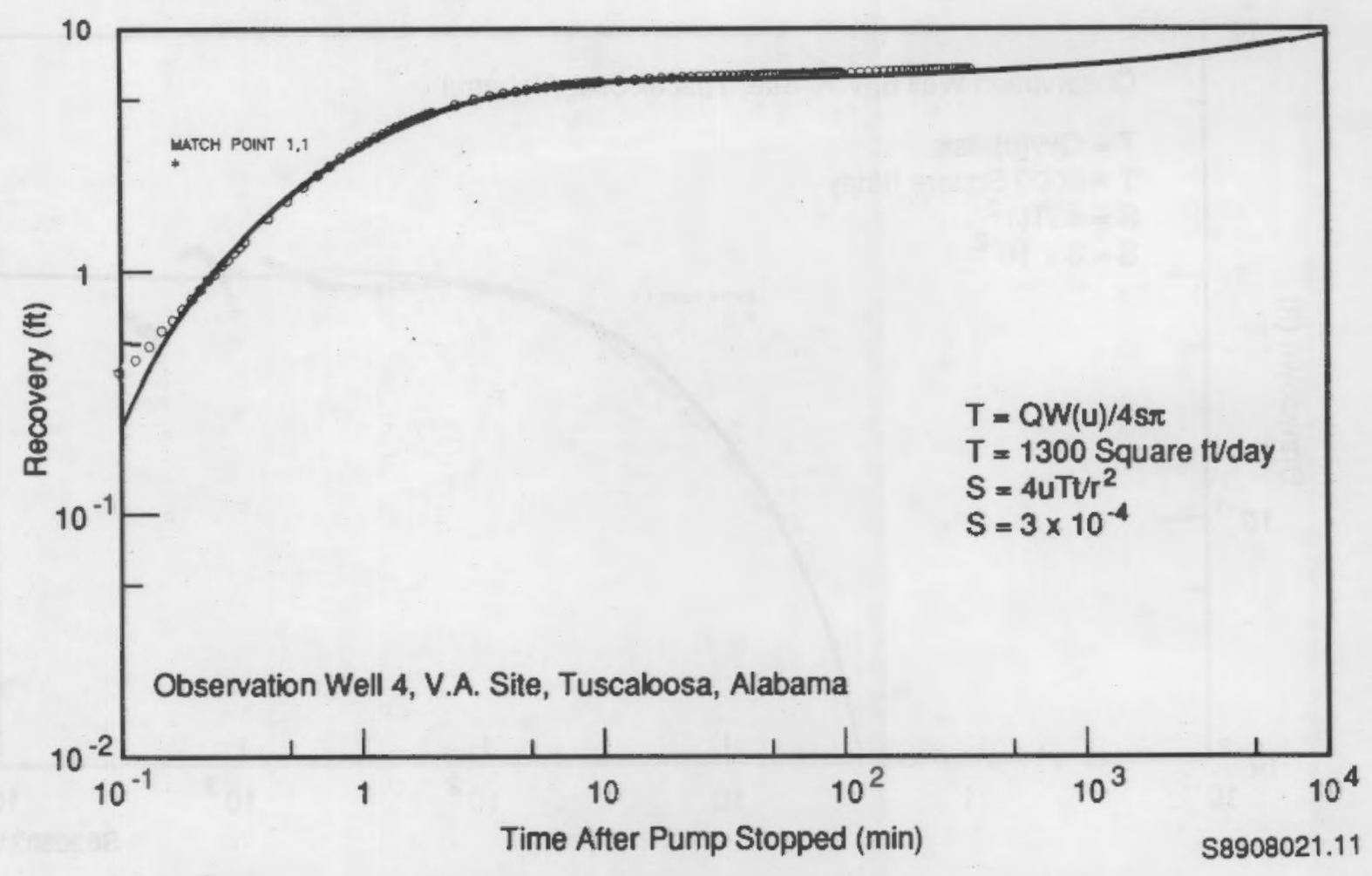

FIGURE C.8. Log-Log Recovery Data and Analysis for Well 4

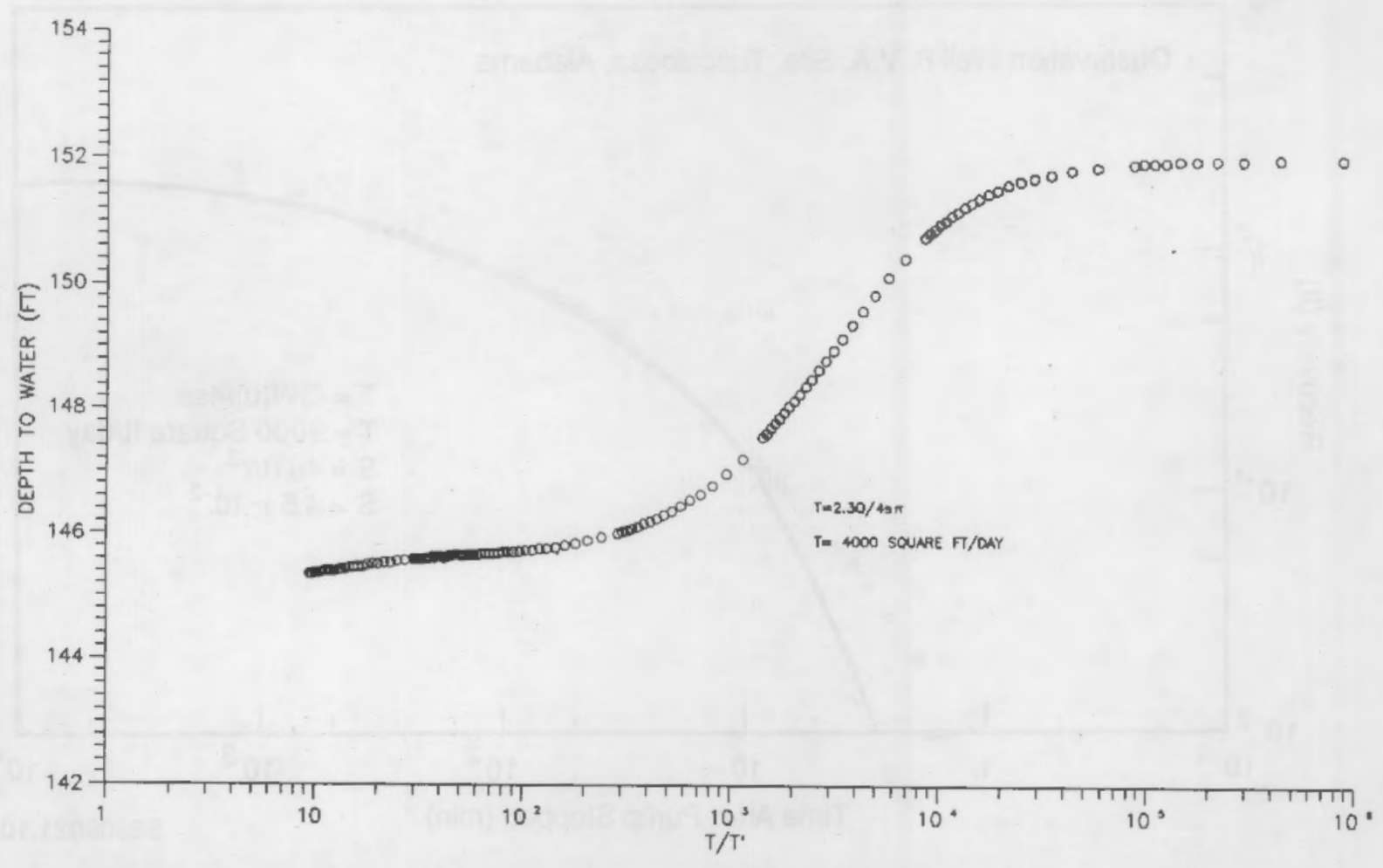

FIGURE C.9. Cooper-Jacob Semilog Recovery Data and Analysis for Well 4 


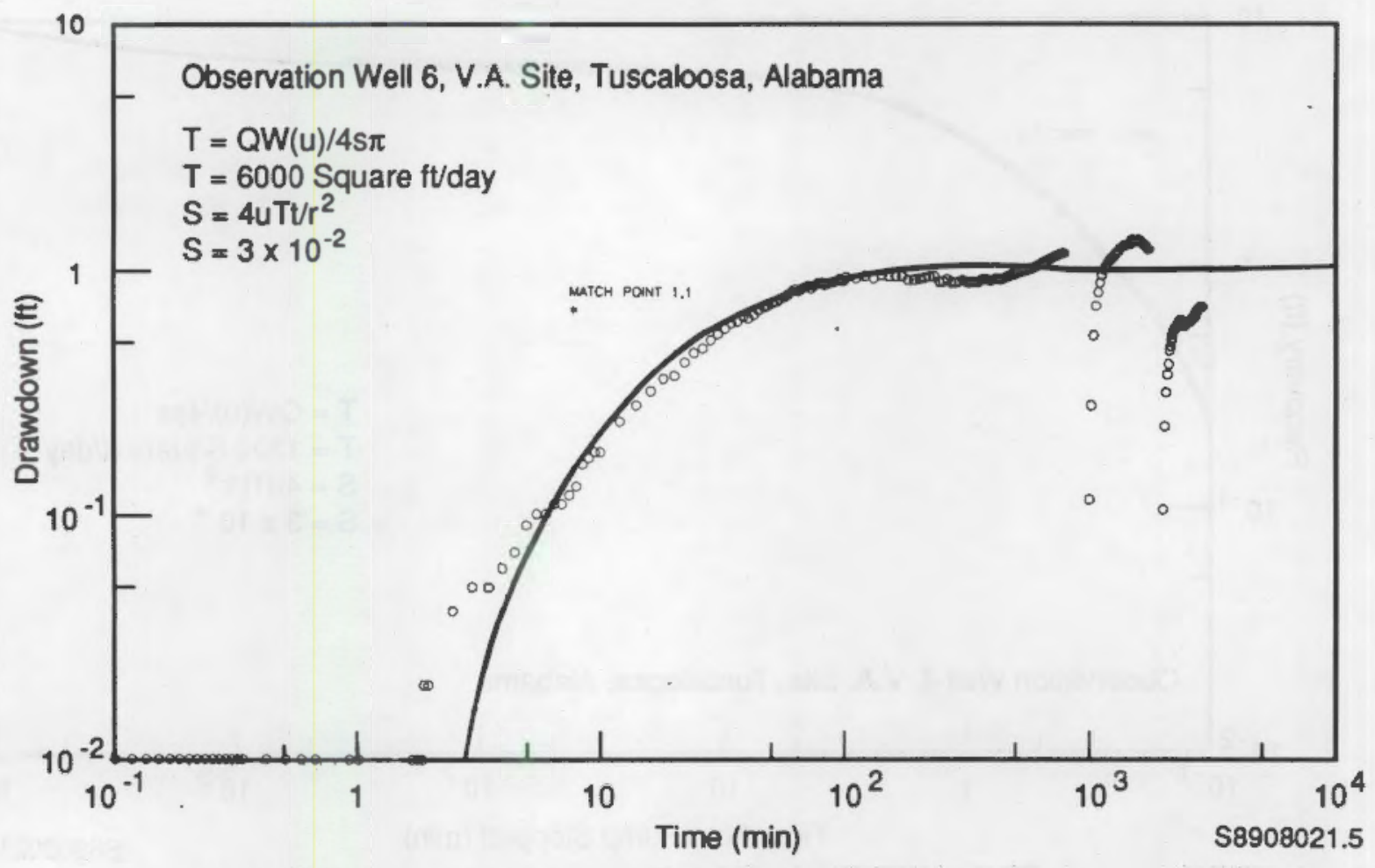

FIGURE C.10. Drawdown Data and Analysis for Well 6

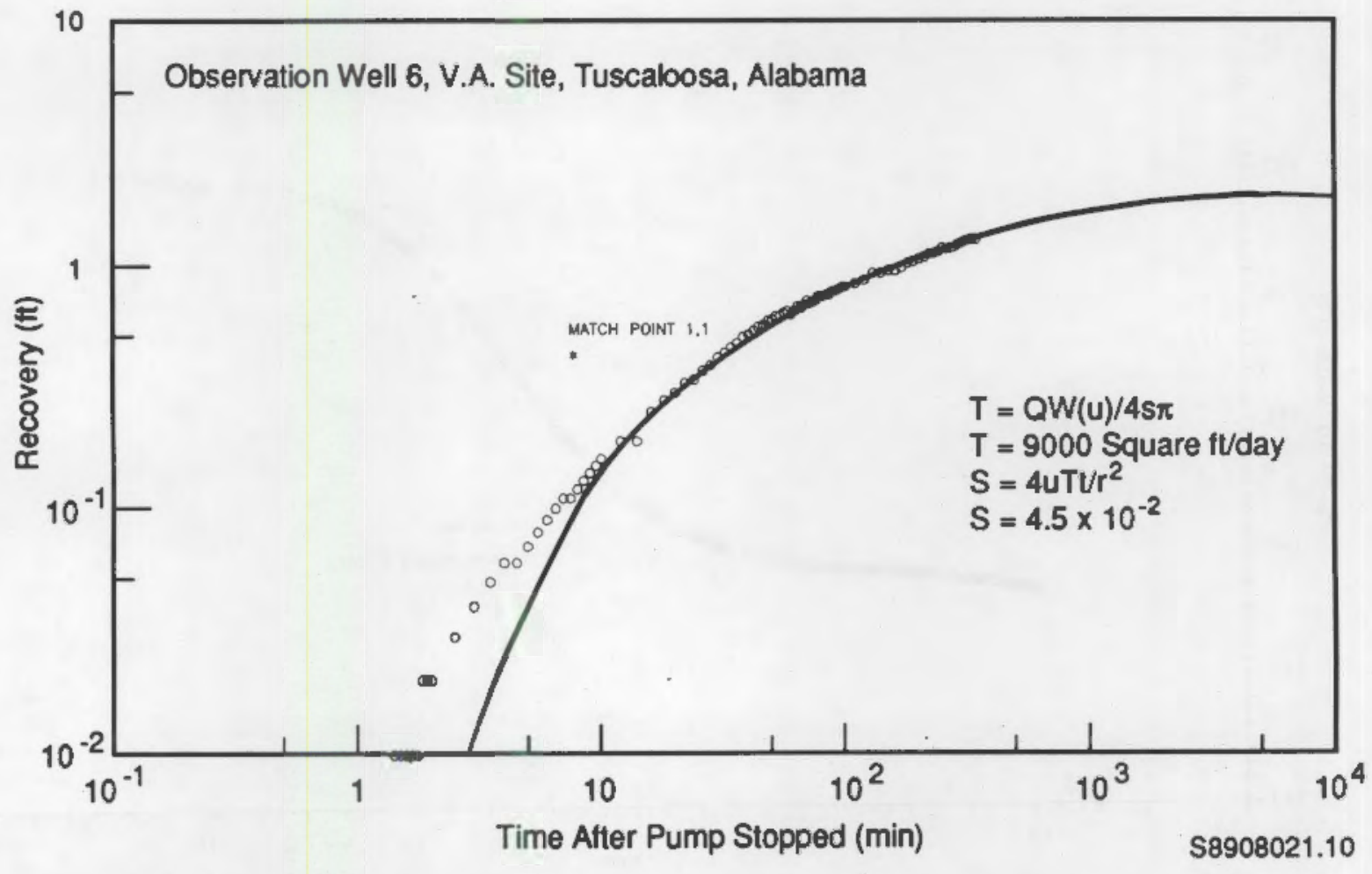

FIGURE C.11. Log-Log Recovery Data and Analysis for Well 6 


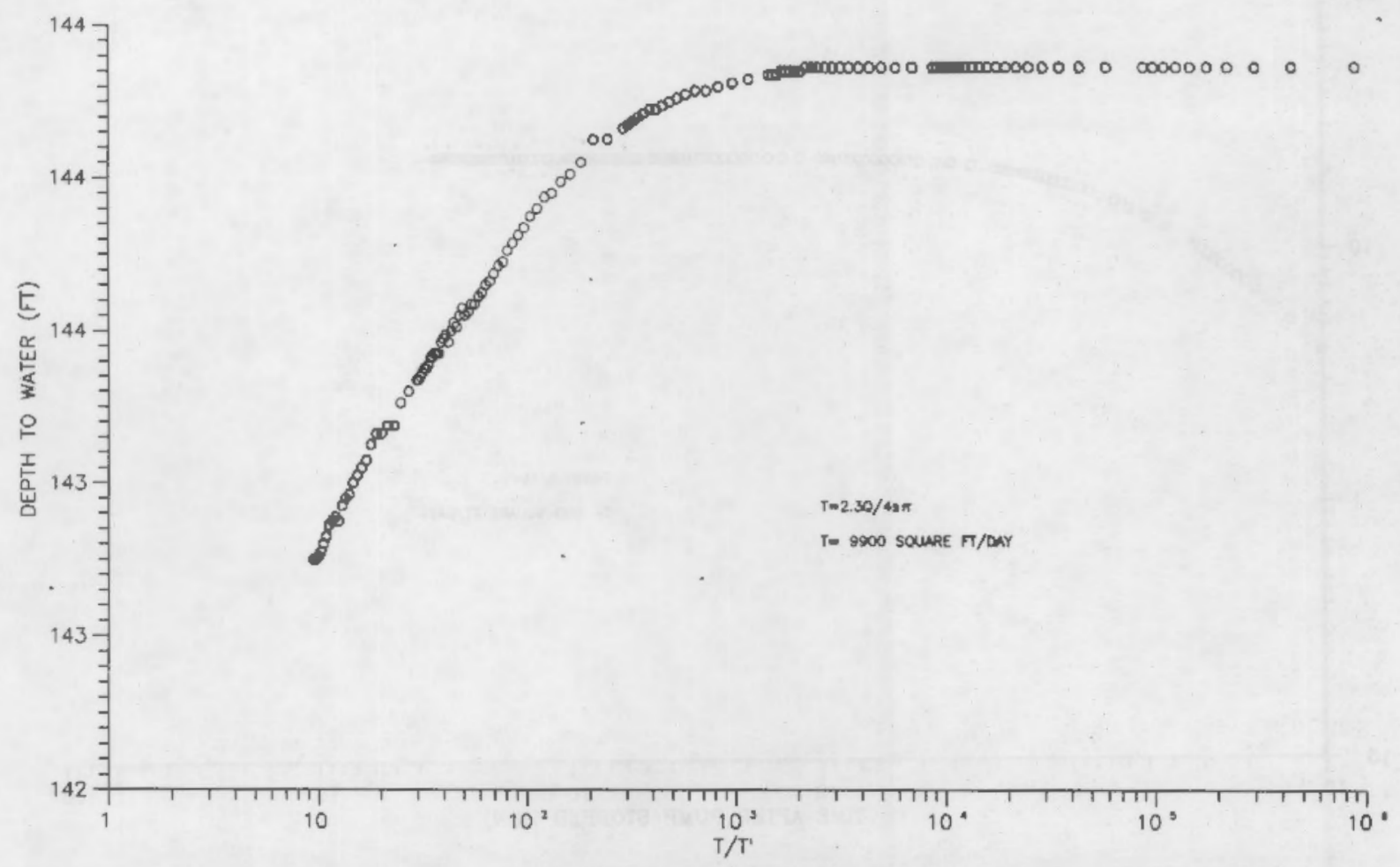

FIGURE C.12. Cooper-Jacob Semilog Recovery Data and Analysis for Well 6

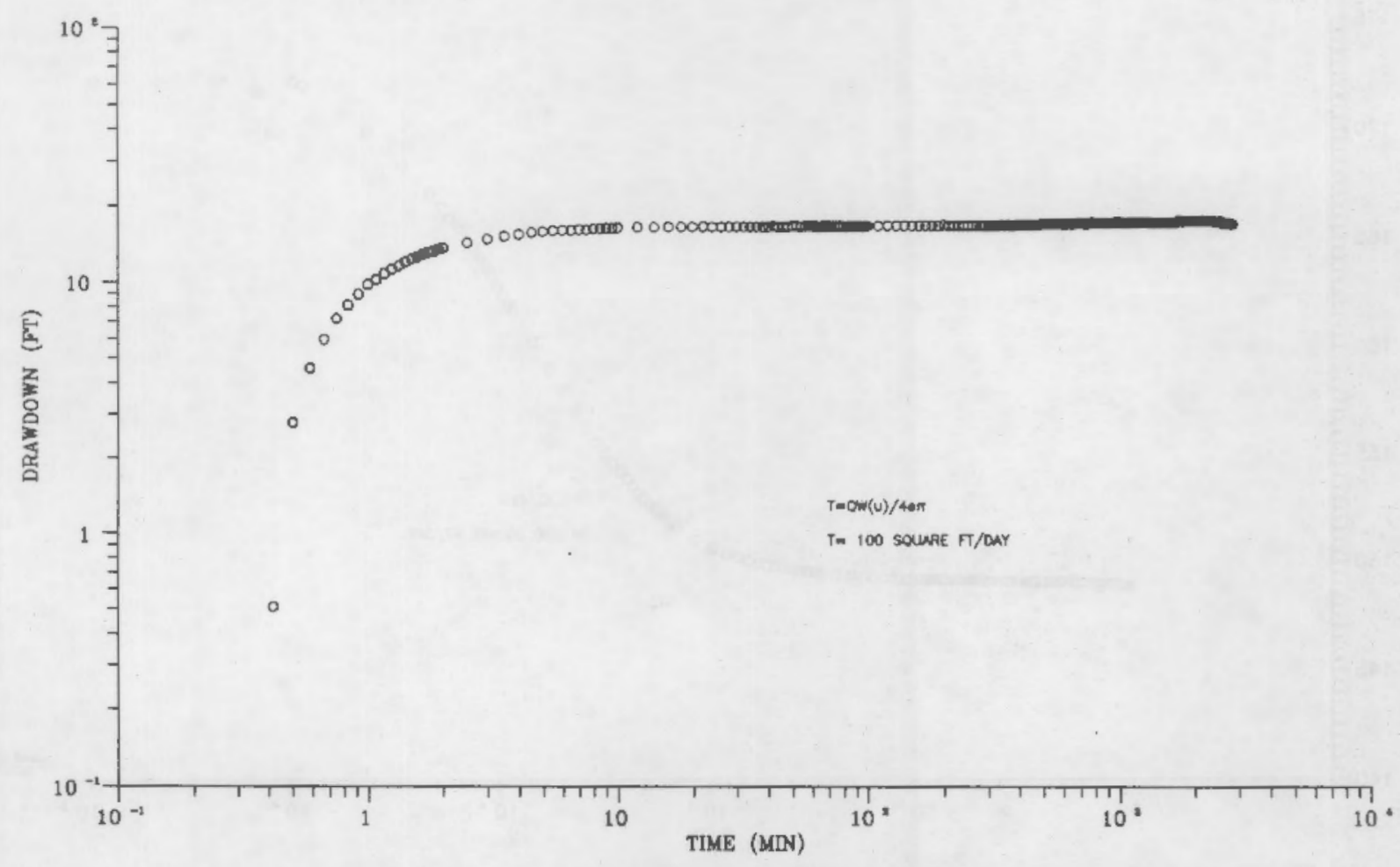

FIGURE C.13. Drawdown Data and Analysis for Well 7

\section{C.7}




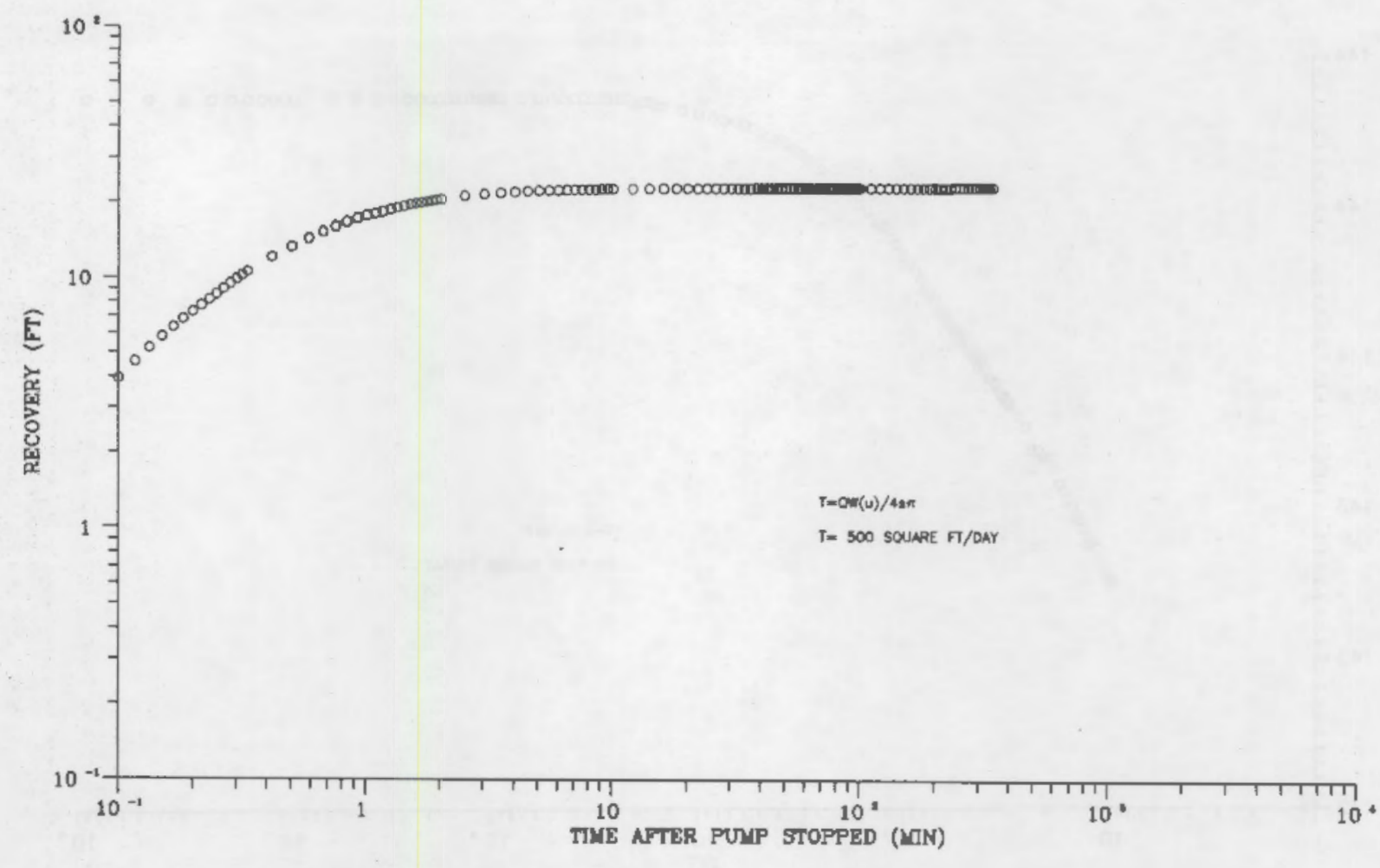

FIGURE C.14. Log-Log Recovery Data and Analysis for Well 7

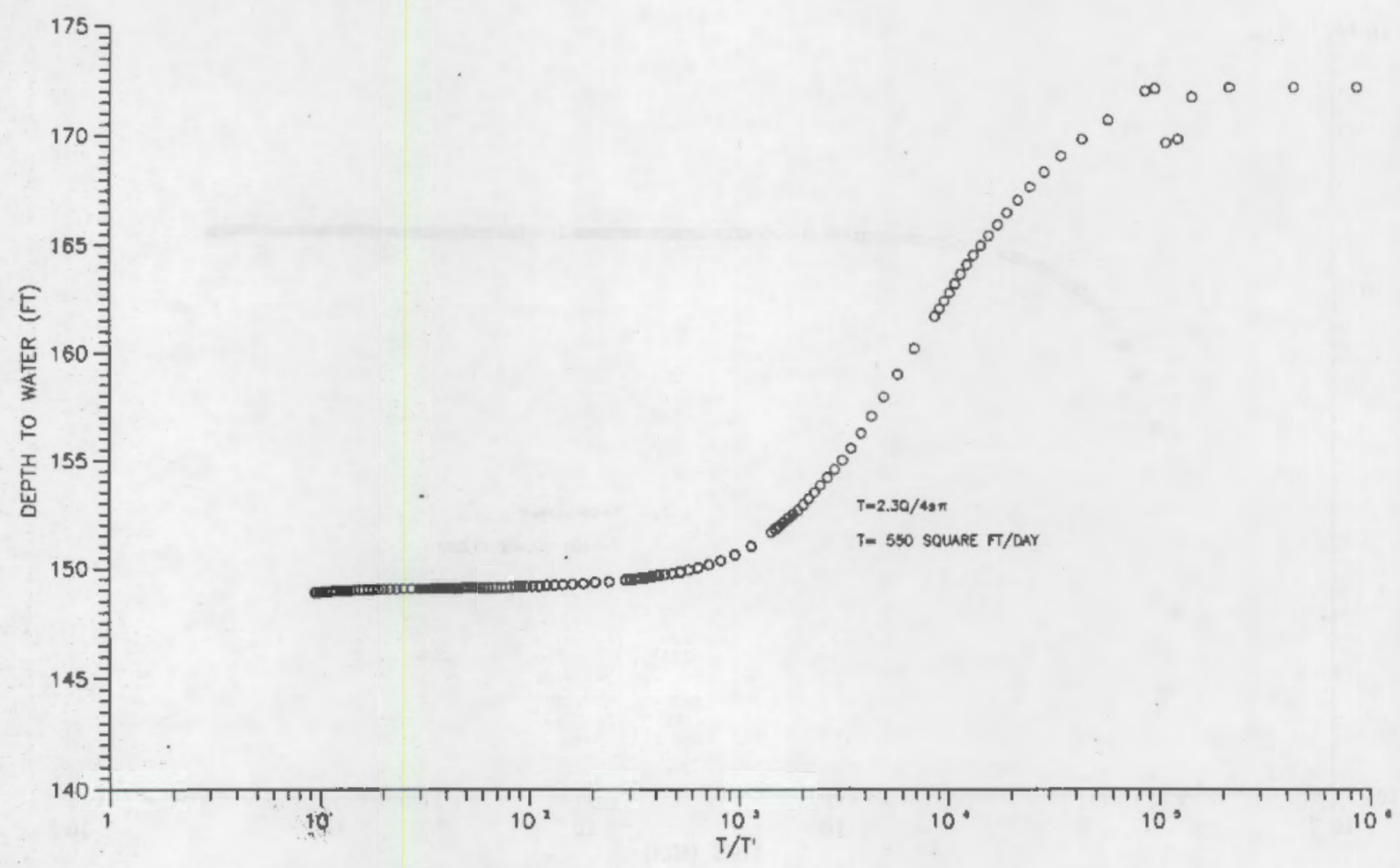

FIGURE C.15. Cooper-Jacob Semilog Recovery Data and Analysis for Well 7

$$
\text { C.8 }
$$




\section{DISTRIBUTION}

No. of

Copies

OFFSITE

U.S. Department of Energy

Attn: K. Klein

Office of Energy Storage \& Dist.

Forrestal B1dg, CE-32 5E-036

Washington, DC 20585

U.S. Department of Energy

Attn: E. Reimers

Office of Energy Storage \& Dist.

Forrestal Bldg, CE-32 5E-036

Washington, DC 20585

12 DOE/Office of Scientific and

Technical Information

University of Alabama

Attn: C. E. Brett

School of Mines and Energy Development.

Box 6282

University, AL 35486

University of Alabama

Attn: Y. K. Song

Box 870276

University, AL 35486
No. of

Copies

ONSITE

DOE Richland Operations Office

D. R. Segna, A5-90

34 Pacific Northwest Laboratory

M. P. Bergeron, $K 6-77$

R. W. Bryce, K6-96

W. E. Cronin, K6-77 (3)

J. W. Falco, K6-78

J. M. Hales, K6-04

S. H. Hall, K6-96

P. C. Hays, K6-86

L. D. Kannberg, K5-21 (10)

S. P. Luttrel1, K6-96

W. T. Pennel1, K6-08

J. R. Raymond, K6-77

R. L. Skaggs, K6-77

J. L. Smoot, K6-77

L. W. Vail, K6-77

R. W. Wallace, K6-77

J. R. Weber, K3-53

R. E. Wildung, P7-50

Publishing Coordination

Technical Report Files

(5) 


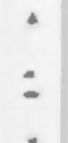

